\title{
Cleanup Verification Package for the 300 VTS Waste Site
}

\author{
Prepared for the U.S. Department of Energy \\ by Washington Closure Hanford
}

March 2006 


\section{EXECUTIVE SUMMARY}

This cleanup verification package documents completion of remedial action for the 300 Area Vitrification Test Site, also known as the 300 VTS site. The 300 VTS site is located within the 300-FF-2 Operable Unit in the 300 Area of the Hanford Site in southeastern Washington State. The site was used by Pacific Northwest National Laboratory during the 1980 s and 1990 s as a field demonstration site for in situ vitrification of soils containing simulated waste. It is an irregularly shaped area approximately 85 by $105 \mathrm{~m}$ ( 280 by $340 \mathrm{ft}$ ) bounded by a security fence with three

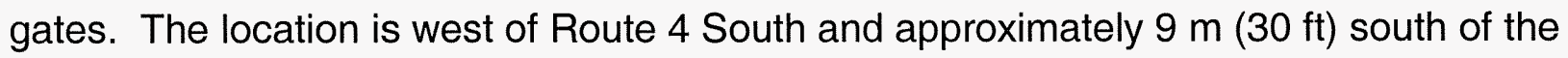
618-7 Burial Ground. The site is not associated with the 618-7 Burial Ground. All contaminated soil and equipment has been removed from the 300 VTS site.

Site excavation and waste disposal are complete, and the exposed surfaces have been sampled and analyzed to verify attainment of the remedial action goals. Results of the sampling, laboratory analyses, and data evaluations for the 300 VTS site indicate that all remedial action objectives and goals for direct exposure, protection of groundwater, and protection of the Columbia River have been met (Table ES-1).

The site meets cleanup standards for unrestricted land use and has been reclassified as "interim closed out" in accordance with the Hanford Federal Facility Agreement and Consent Order (Ecology et al. 1989) and the Waste Site Reclassification Guideline TPA-MP-14 (RL-TPA-90-0001) (DOE-RL 1998). A copy of the waste site reclassification form is included as Attachment ES-1. 


\section{Table ES-1. Summary of Cleanup Verification Results for the 300 VTS Waste Site - Unrestricted Land Use.}

\begin{tabular}{|c|c|c|c|}
\hline $\begin{array}{l}\text { Regulatory } \\
\text { Requirement }\end{array}$ & Remedial Action Goals & Results & $\begin{array}{l}\text { Remedial } \\
\text { Action } \\
\text { Objectives } \\
\text { Attained? }\end{array}$ \\
\hline $\begin{array}{l}\text { Direct Exposure - } \\
\text { Radionuclides }\end{array}$ & $\begin{array}{l}\text { Attain } 15 \mathrm{mrem} / \mathrm{yr} \text { dose rate above } \\
\text { background over } 1,000 \text { years. Attain } \\
\text { the CERCLA risk range of } 10^{-4} \text { to } \\
10^{-6} \text {. }\end{array}$ & $\begin{array}{l}\text { Of the radionuclide COCs, only } \\
\text { cesium- } 137 \text { was detected, at a } \\
\text { statistical activity below the direct } \\
\text { exposure dose equivalence value for } \\
\text { an unrestricted land-use scenario. }\end{array}$ & Yes \\
\hline $\begin{array}{l}\text { Direct Exposure - } \\
\text { Nonradionuclides }\end{array}$ & Attain individual COC RAGs. & $\begin{array}{l}\text { All individual COC concentrations are } \\
\text { below the RAGs. }\end{array}$ & Yes \\
\hline \multirow{4}{*}{$\begin{array}{l}\text { Meet } \\
\text { Nonradionuclide Risk } \\
\text { Requirements }\end{array}$} & $\begin{array}{l}\text { Hazard quotient of }<1 \text { for } \\
\text { noncarcinogens. }\end{array}$ & \multirow{2}{*}{$\begin{array}{l}\text { Hazard quotients were not calculated } \\
\text { because no nonradionuclide COCs } \\
\text { were analyzed above chemical } \\
\text { detection limits for this site. }\end{array}$} & \multirow{4}{*}{ Yes } \\
\hline & $\begin{array}{l}\text { Cumulative hazard quotient of }<1 \text { for } \\
\text { noncarcinogens. }\end{array}$ & & \\
\hline & $\begin{array}{l}\text { Excess cancer risk of }<1 \times 10^{-5} \text { for } \\
\text { individual carcinogens. }\end{array}$ & \multirow{2}{*}{$\begin{array}{l}\text { Excess cancer risks were not } \\
\text { calculated because no nonradionuclide } \\
\text { COCs were analyzed above chemical } \\
\text { detection limits for this site. }\end{array}$} & \\
\hline & $\begin{array}{l}\text { Attain a total excess cancer risk of } \\
<1 \times 10^{-5} \text { for carcinogens. }\end{array}$ & & \\
\hline \multirow{4}{*}{$\begin{array}{l}\text { Groundwater/River } \\
\text { Protection - } \\
\text { Radionuclides }\end{array}$} & $\begin{array}{l}\text { Attain single-COC groundwater and } \\
\text { river protection RAGs. }\end{array}$ & $\begin{array}{l}\text { All single-COC groundwater and river } \\
\text { RAGs have been attained. }\end{array}$ & \multirow{4}{*}{ Yes } \\
\hline & $\begin{array}{l}\text { Attain National Primary Drinking } \\
\text { Water Standards: } 4 \mathrm{mrem} / \mathrm{yr} \\
\text { (beta/gamma) dose rate to target } \\
\text { receptor/organs. }\end{array}$ & $\begin{array}{l}\text { Of the radionuclide COCs, only } \\
\text { cesium- } 137 \text { was detected at the site. } \\
\text { Cesium-137 is not predicted to reach } \\
\text { groundwater or the Columbia River } \\
\text { within } 1,000 \text { years (DOE-RL 2004b). }\end{array}$ & \\
\hline & $\begin{array}{l}\text { Meet drinking water standards for } \\
\text { nonuranium alpha emitters: the } \\
\text { more stringent of the } 15 \mathrm{pCi} / \mathrm{L} \mathrm{MCL} \\
\text { or } 1 / 25 \text { th of the derived } \\
\text { concentration guide per } \\
\text { DOE Order } 5400.5 \text {. }\end{array}$ & $\begin{array}{l}\text { No alpha-emitting radionuclide COCs } \\
\text { were detected above background } \\
\text { levels for this site. }\end{array}$ & \\
\hline & $\begin{array}{l}\text { Meet total uranium standard of } \\
21.2 \mathrm{pCi} / \mathrm{L}^{2}\end{array}$ & $\begin{array}{l}\text { No uranium was detected above } \\
\text { background levels for this site. }\end{array}$ & \\
\hline $\begin{array}{l}\text { Groundwater/River } \\
\text { Protection - } \\
\text { Nonradionuclides }\end{array}$ & $\begin{array}{l}\text { Attain individual nonradionuclide } \\
\text { groundwater and river cleanup } \\
\text { requirements. }\end{array}$ & $\begin{array}{l}\text { No nonradionuclide COCs were } \\
\text { analyzed above chemical detection } \\
\text { limits for this site. }\end{array}$ & Yes \\
\hline $\begin{array}{l}\text { Supporting } \\
\text { Information }\end{array}$ & \multicolumn{3}{|c|}{$\begin{array}{l}\text { Cleanup verification } 95 \% \text { UCL calculation (Appendix } \mathrm{C})^{\mathrm{b}} \\
\text { Cleanup verification sample location design (Appendix } \mathrm{C} \text { ). }{ }^{\mathrm{c}}\end{array}$} \\
\hline
\end{tabular}

\footnotetext{
${ }^{a}$ Based on the isotopic distribution of uranium in the Hanford Site background, the $30 \mu \mathrm{g} / \mathrm{L} \mathrm{MCL}$ (65 Federal Register 76708) corresponds to $21.2 \mathrm{pCi} / \mathrm{L}$. Concentration-to-activity calculations are documented in Calculation of Total Uranium Activity Corresponding to a Maximum Contaminant Level for Total Uranium of 30 Micrograms per Liter in Groundwater, 0100X-CA-V0038 (BHI 2001).

b 300 VTS Cleanup Verification 95\% UCL Calculation, 0300X-CA-V0059, Rev. 0, Washington Closure Hanford, Richland, Washington.

'300 VTS Site Shallow Zone Sampling Plan, 0300X-CA-V0060, Rev. 1, Washington Closure Hanford, Richland, Washington. CERCLA = Comprehensive Environmental Response, Compensation, and Liability Act of 1980

COC = contaminant of concern

$\mathrm{MCL} \quad=$ maximum contaminant level (drinking water standard)

RAG = remedial action goal

UCL = upper confidence limit
} 
CVP-2005-00009

Rev. 0

Attachment ES-1

Waste Site Reclassification Form

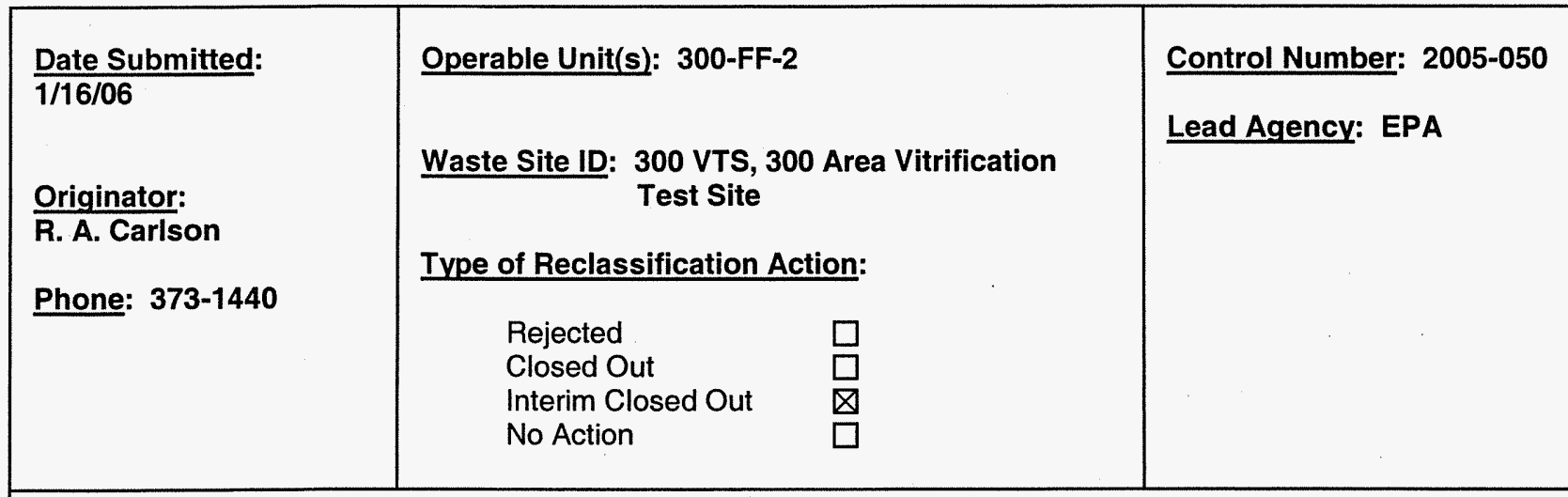

This form documents agreement among the parties listed below authorizing classification of the subject unit as rejected, closed out, or no action and authorizing backfill of the site, if appropriate. Final removal from the National Priorities List of no action or closed-out sites will occur at a future date.

\section{Description of current waste site condition:}

Remedial action at this site has been performed in accordance with remedial action objectives and goals established by the U.S. Environmental Protection Agency and the U.S. Department of Energy, Richland Operations Office, in concurrence with the Washington State Department of Ecology. The selected remedial action involved

(1) excavating the site to the extent required to meet specified soil cleanup levels, (2) disposing of contaminated excavated materials at the Environmental Restoration Disposal Facility in the 200 Area of the Hanford Site, and (3) backfilling the site with clean soil and grading to match the surrounding surface. The excavation and disposal activities have been completed.

\section{Basis for reclassification:}

The 300 VTS waste site has been remediated to meet the cleanup standards specified in the Record of Decision for the 300-FF-2 Operable Unit, Hanford Site, as modified by the Explanation of Significant Differences for the $300-F F-2$ Operable Unit Interim Record of Decision (U.S. Environmental Protection Agency, Region 10, Seattle, Washington). Remedial actions were performed to support unrestricted land use of the shallow zone (i.e., surface to $4.6 \mathrm{~m}$ [15 ft] deep) and to protect groundwater and the Columbia River. This site has no deep zone; therefore, no deep zone institutional controls are required. The basis for reclassification is described in detail in the Cleanup Verification Package for the 300 VTS Waste Site (CVP-2005-00009), Washington Closure Hanford, Richland, Washington.

D. C. Smith

DOE-RL Project Manager

N/A

Ecology Project Manager

A. Boyd

EPA Project Manager
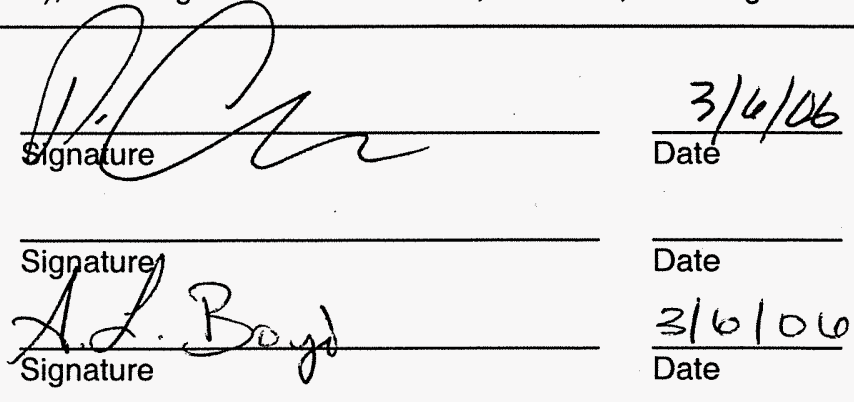
CVP-2005-00009

Rev. 0

ES-4 


\section{CONTENTS}

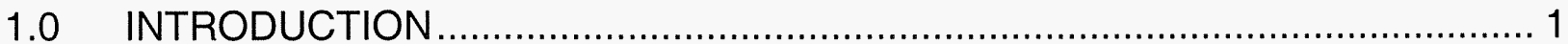

2.0 SITE DESCRIPTION AND SUPPORTING INFORMATION .............................. 2

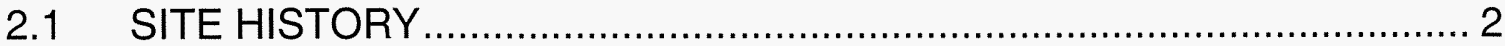

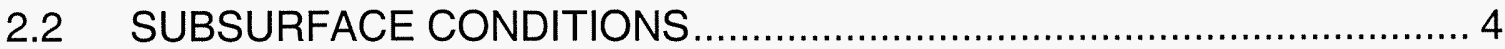

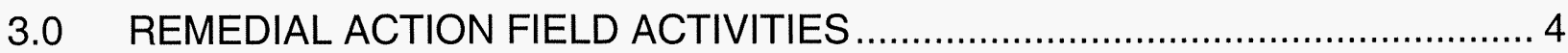

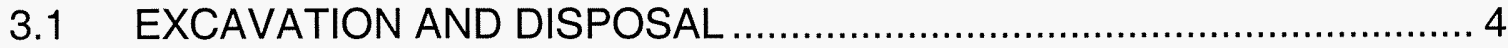

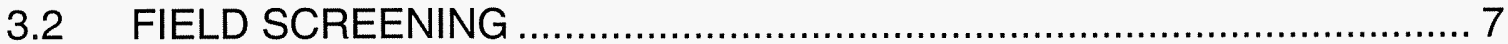

3.3 BIASED SAMPLING AND ANALYSIS ............................................ 7

3.4 CLEANUP VERIFICATION SAMPLING AND ANALYSIS ...................... 7

4.0 CLEANUP VERIFICATION DATA EVALUATION …….................................. 12

4.1 DATA QUALITY ASSESSMENT PROCESS ..................................... 12

4.2 CONTAMINANTS OF CONCERN 95\% UPPER CONFIDENCE LIMIT ... 12

4.3 SITE-SPECIFIC CLEANUP VERIFICATION MODEL $\ldots \ldots \ldots \ldots \ldots \ldots \ldots \ldots \ldots \ldots$

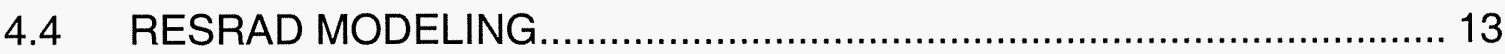

5.0 EVALUATION OF REMEDIAL ACTION GOAL ATTAINMENT FOR UNRESTRICTED LAND USE .............................................................. 14

5.1 DIRECT EXPOSURE SOIL REMEDIAL ACTION GOALS ATTAINED.... 14

5.1.1 Radionuclides .................................................................. 14

5.1.2 Nonradionuclides .............................................................. 15

5.2 GROUNDWATER REMEDIAL ACTION GOALS ATTAINED ................ 15

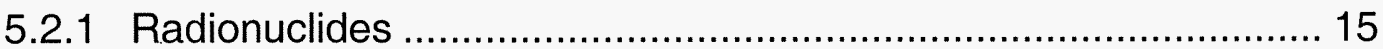

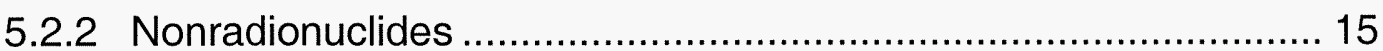

5.3 COLUMBIA RIVER REMEDIAL ACTION GOALS ATTAINED ............... 16

5.3.1 Radionuclides ................................................................... 16

5.3.2 Nonradionuclides ............................................................... 16

5.4 WAC 173-340 THREE-PART TEST FOR NONRADIONUCLIDES ......... 16

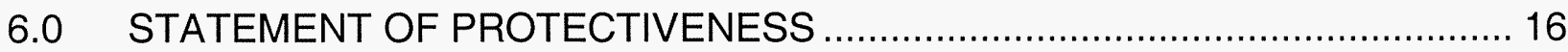

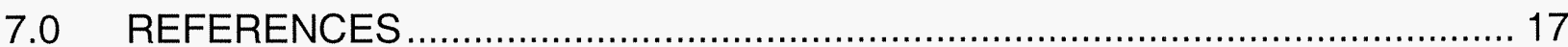




\section{APPENDICES}

A SUMMARY OF VERIFICATION SOIL SAMPLING AND ANALYTICAL

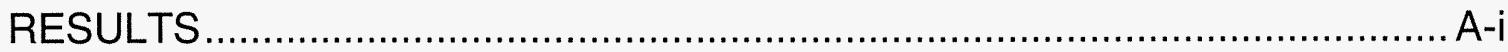

B DATA QUALITY ASSESSMENT FOR THE 300 VTS WASTE SITE ................ B-i

C CALCULATION BRIEF EXCERPTS ………..............................................

C1 300 VTS Site Shallow Zone Sampling Plan, 0300X-CA-V0060 .................-3

C2 300 VTS Cleanup Verification 95\% UCL Calculation, 0300X-CA-V0059....C-9

\section{FIGURES}

1. Hanford Site Map and Location of the 300 VTS Site......................................... 3

2. Pre-Remediation Topographic Plan for the 300 VTS Site. .................................. 5

3. Post-Remediation Topographic Plan for the 300 VTS Site.................................. 6

4. $\quad 300$ VTS Ground Disturbance Area Gamma Track Map. .................................. 8

5. $\quad 300$ VTS Ground Disturbance Area Beta Track Map...................................... 9

6. $\quad 300$ VTS Excavated Area Gamma Track Map................................................ 10

7. $\quad 300$ VTS Excavated Area Beta Track Map..................................................... 11

\section{TABLES}

1. Summary of Remedial Action Goals............................................................ 1

2. Cleanup Verification Data Set. ................................................................ 14 


\section{ACRONYMS AND ABBREVIATIONS}

$\begin{array}{ll}\text { COC } & \text { contaminant of concern } \\ \text { COPC } & \text { contaminant of potential concern } \\ \text { DQA } & \text { data quality assessment } \\ \text { ERDF } & \text { Environmental Restoration Disposal Facility } \\ \text { ESD } & \begin{array}{l}\text { explanation of significant differences } \\ \text { ISV }\end{array} \\ \text { in situ vitrification } \\ \text { PNNL } & \text { Pacific Northwest National Laboratory } \\ \text { RAG } & \text { remedial action goal } \\ \text { RAO } & \text { remedial action objective } \\ \text { RDR/RAWP } & \text { remedial design report/remedial action work plan } \\ \text { RESRAD } & \text { RESidual RADioactivity dose assessment model } \\ \text { ROD } & \text { record of decision } \\ \text { SAP } & \text { sampling and analysis plan } \\ \text { UCL } & \text { upper confidence limit } \\ \text { WAC } & \text { Washington Administrative Code }\end{array}$


CVP-2005-00009

Rev. 0 


\subsection{INTRODUCTION}

The purpose of this cleanup verification package is to document that the 300 Area Vitrification Test Site (300 VTS site) was remediated in accordance with the Record of Decision for the 300-FF-2 Operable Unit, Hanford Site (ROD) (EPA 2001), as modified by the Explanation of Significant Differences for the 300-FF-2 Operable Unit Interim Record of Decision (ESD) (EPA 2004). Remedial action objectives (RAOs) and remedial action goals (RAGs) for the 300 VTS site are documented in the ROD (EPA 2001) and the Remedial Design Report/Remedial Action Work Plan for the 300 Area (RDR/RAWP) (DOE-RL 2004b). The ROD provides the U.S. Department of Energy, Richland Operations Office the authority, guidance, and objectives to conduct this remedial action.

The preferred remedy specified in the ROD (EPA 2001) and conducted for the 300 VTS site included (1) excavating the site to the extent required to meet specified soil cleanup levels, (2) disposing of contaminated excavated materials at the Environmental Restoration Disposal Facility (ERDF) at the 200 Areas of the Hanford Site, and (3) backfilling the site with clean soil to match surrounding grade elevation. Excavation was driven by RAOs for direct exposure, protection of groundwater, and protection of the Columbia River. Preliminary waste site contaminants of potential concern (COPCs) were identified in the 300 Area Remedial Action Sampling and Analysis Plan (SAP) (DOE-RL 2004a). Following excavation of the site, final contaminants of concern (COCs) were identified in the Closeout Plan for Waste Site 300 VTS (WCH 2005) and are listed in Table 1.

Table 1. Summary of Remedial Action Goals. (2 Pages)

\begin{tabular}{|l|c|c|c|}
\hline \multicolumn{1}{|c|}{$\begin{array}{c}\text { Contaminants of Concern } \\
\text { (COCs) }\end{array}$} & $\begin{array}{c}\text { Unrestricted } \\
\text { Soil Cleanup } \\
\text { Level for Direct } \\
\text { Exposure } \\
\text { (pCi/g) }\end{array}$ & $\begin{array}{c}\text { Soil Cleanup } \\
\text { Level for } \\
\text { Groundwater } \\
\text { Protection } \\
\text { (pCi/g) }\end{array}$ & $\begin{array}{c}\text { Soil Cleanup } \\
\text { Level for River } \\
\text { Protection } \\
\text { (pCi/g) }\end{array}$ \\
\hline \multicolumn{4}{|c|}{ Radionuclides } \\
\hline Americium-241 & 32.1 & NA & NA \\
\hline Cesium-137 & 6.2 & NA & NA \\
\hline Cobalt-60 & 1.4 & NA & NA \\
\hline Plutonium-238 & 38.8 & NA & NA \\
\hline Plutonium-239/240 & 35.1 & NA & NA \\
\hline Ruthenium-106 & 17.2 & NA & NA \\
\hline Strontium-90 & 4.5 & NA & NA \\
\hline
\end{tabular}


Table 1. Summary of Remedial Action Goals. (2 Pages)

\begin{tabular}{|l|c|c|c|}
\hline $\begin{array}{c}\text { Contaminants of Concern } \\
\text { (COCs) }\end{array}$ & $\begin{array}{c}\text { Unrestricted } \\
\text { Soil Cleanup } \\
\text { Level for Direct } \\
\text { Contact } \\
(\mathrm{mg} / \mathrm{kg})\end{array}$ & $\begin{array}{c}\text { Soil Cleanup } \\
\text { Level for } \\
\text { Groundwater } \\
\text { Protection } \\
\text { (mg/kg) }\end{array}$ & $\begin{array}{c}\text { Soil Cleanup } \\
\text { Level for River } \\
\text { Protection } \\
\text { (mg/kg) }\end{array}$ \\
\hline \multicolumn{4}{|c|}{ Nonradionuclides } \\
\hline PCBs & $0.5^{c}$ & NA & NA \\
\hline
\end{tabular}

${ }^{a}$ Listed values represent a $15 \mathrm{mrem} / \mathrm{yr}$ dose in the unrestricted land-use scenario, calculated using RESRAD, based on the generic site model for the 300 Area (DOE-RL 2004b).

${ }^{b}$ RESRAD modeling predicts the constituent will not reach groundwater within 1,000 years based on the 300 Area generic site model (DOE-RL 2004b).

${ }^{c}$ Cleanup level calculated using WAC 173-340-740(3) Method B cleanup standards for residential soil with a cancer potency factor of $2.0 \mathrm{mg} / \mathrm{kg}$ per day.

$\mathrm{NA} \quad=$ not applicable

$\mathrm{PCB} \quad=$ polychlorinated biphenyl

RESRAD = RESidual RADioactivity (dose assessment model)

WAC = Washington Administrative Code

\subsection{SITE DESCRIPTION AND SUPPORTING INFORMATION}

\subsection{SITE HISTORY}

The 300 VTS site is located in the 300-FF-2 Operable Unit of the 300 Area, west of

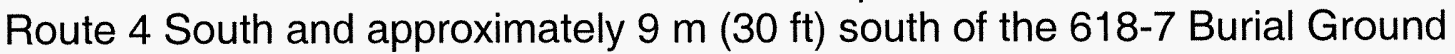
(Figure 1). It is an irregularly shaped area approximately 85 by $104 \mathrm{~m}$ ( 280 by $340 \mathrm{ft}$ ) surrounded by a security fence with three gates. The site was not associated with the nearby 618-7 Burial Ground. The site was used by Pacific Northwest National Laboratory (PNNL) between 1983 and 1986 as a field demonstration site for in situ vitrification (ISV) of soils containing simulated waste (BHI 1994). After the vitrification tests were conducted in the 1980s, all contaminated soil and equipment was removed from the site. In 1993 a large-scale melter (the Terra-Vit) was constructed at the site but never used. During 1998 and 1999 the ISV site was cleaned up by PNNL for transfer to the Bechtel Hanford, Inc. surveillance and maintenance program (BHI 1999). It was confirmed that no radiological contamination remained at the site, and all miscellaneous materials and equipment were removed, including three ore cars contaminated from previous use at a thorium mine. Several large ISV melter structures remained on the site, including the Terra-Vit. 
Figure 1. Hanford Site Map and Location of the 300 VTS Site.

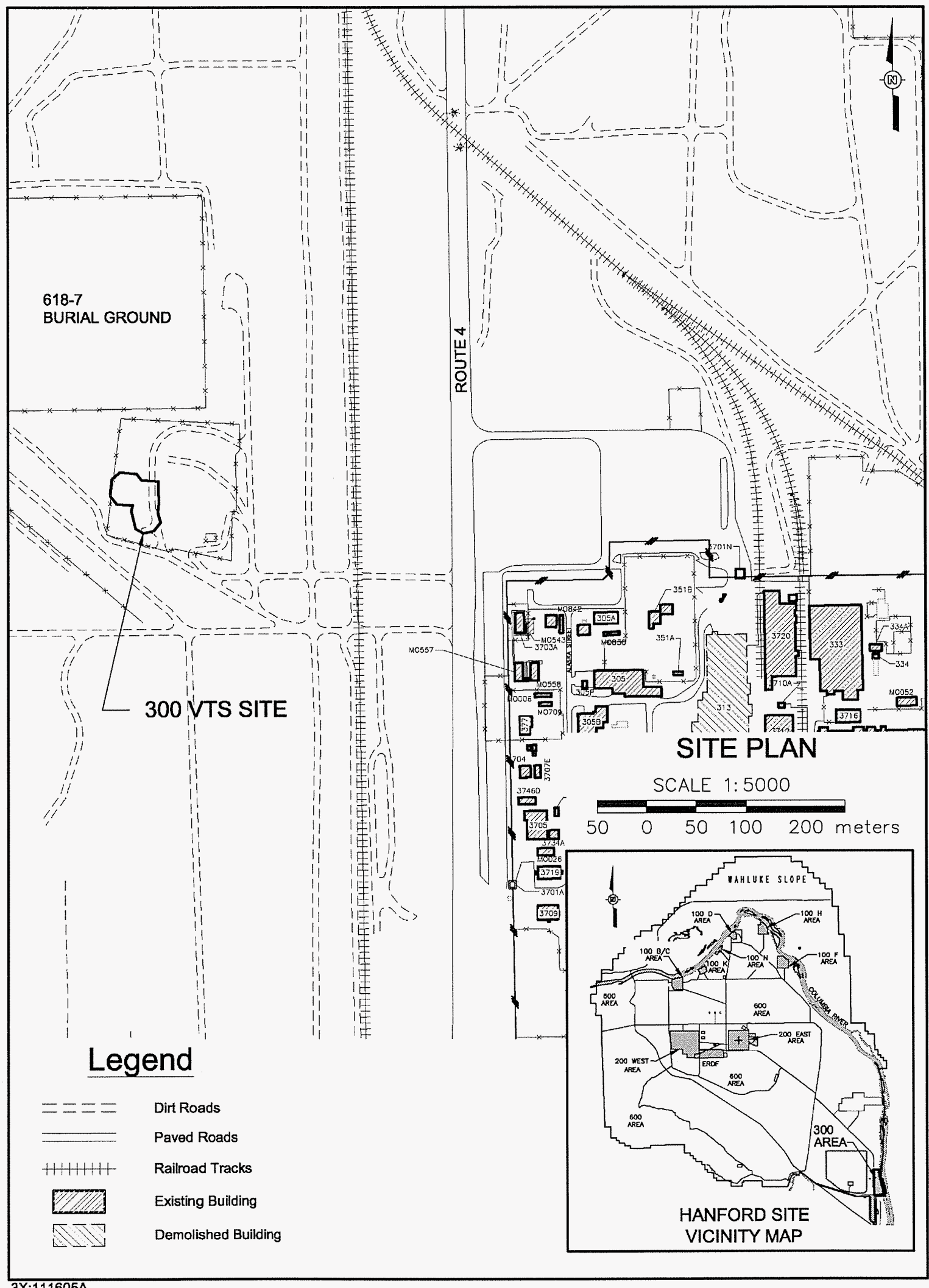




\subsection{SUBSURFACE CONDITIONS}

The soil column (vadose zone) underlying the waste site and extending to groundwater consists of the Hanford and Ringold Formations. The shallower Hanford Formation consists predominantly of medium-dense to dense sand and gravel, with varying amounts of silt and cobble. The underlying Ringold Formation consists of dense, wellcemented gravels with sand and silt interbedding. The Hanford/Ringold contact is approximately 9 to $21 \mathrm{~m}$ (30 to $69 \mathrm{ft}$ ) below the surface grade level.

The long-term groundwater level, beneath the site, is estimated at El. $105.4 \mathrm{~m}$ (346 ft) above mean sea level (North American Vertical Datum of 1988) based on historical and current information from nearby groundwater wells. Groundwater levels are influenced by the nearby Columbia River and other factors such as atmospheric pressure. The depth to groundwater is approximately $15 \mathrm{~m}(48 \mathrm{ft})$ beneath surface grade level.

\subsection{REMEDIAL ACTION FIELD ACTIVITIES}

\subsection{EXCAVATION AND DISPOSAL}

Remedial action at the 300 VTS site began in December 2004. Figure 2 is the preremediation topographic plan for the site. The ISV melter structure was demolished using mechanical shears. The off-gas containment hood was sheared and sent to ERDF for disposal. The support frame was sheared and the scrap metal recycled.

The Terra-Vit melter, fabricated from large structural steel members surrounded by a refractory concrete lining, was demolished using an excavator and mechanical shears. The refractory lining was sent to a demolition landfill (Pit 9), and the structural steel was recycled.

Buried vitrified monoliths, identified by the geophysical survey in two separate areas (Bergstrom and Mitchell 2002), were excavated and size reduced using a hydraulic impact breaker. The rubble was then sent to Pit 9 for disposal. All rubble met the requirements of the new (February 2005) inert landfill regulation (Washington Administrative Code [WAC] 173-350-410). Two test trenches were also excavated, the locations of which were based on historical information and geophysical anomalies. No soil contamination, except cesium-137, which is below the RAGs (Table 1), was found in the test trenches. Figure 3 shows the post-remediation topographic plan for the site, including the excavation area for the monoliths and the two test trenches.

Miscellaneous debris, consisting of buried graphite electrodes and pipe casings, were excavated from several vitrification test locations at the site. The graphite electrodes were sent to ERDF, and the pipe casings were recycled. 
Figure 2. Pre-Remediation Topographic Plan for the 300 VTS Site.

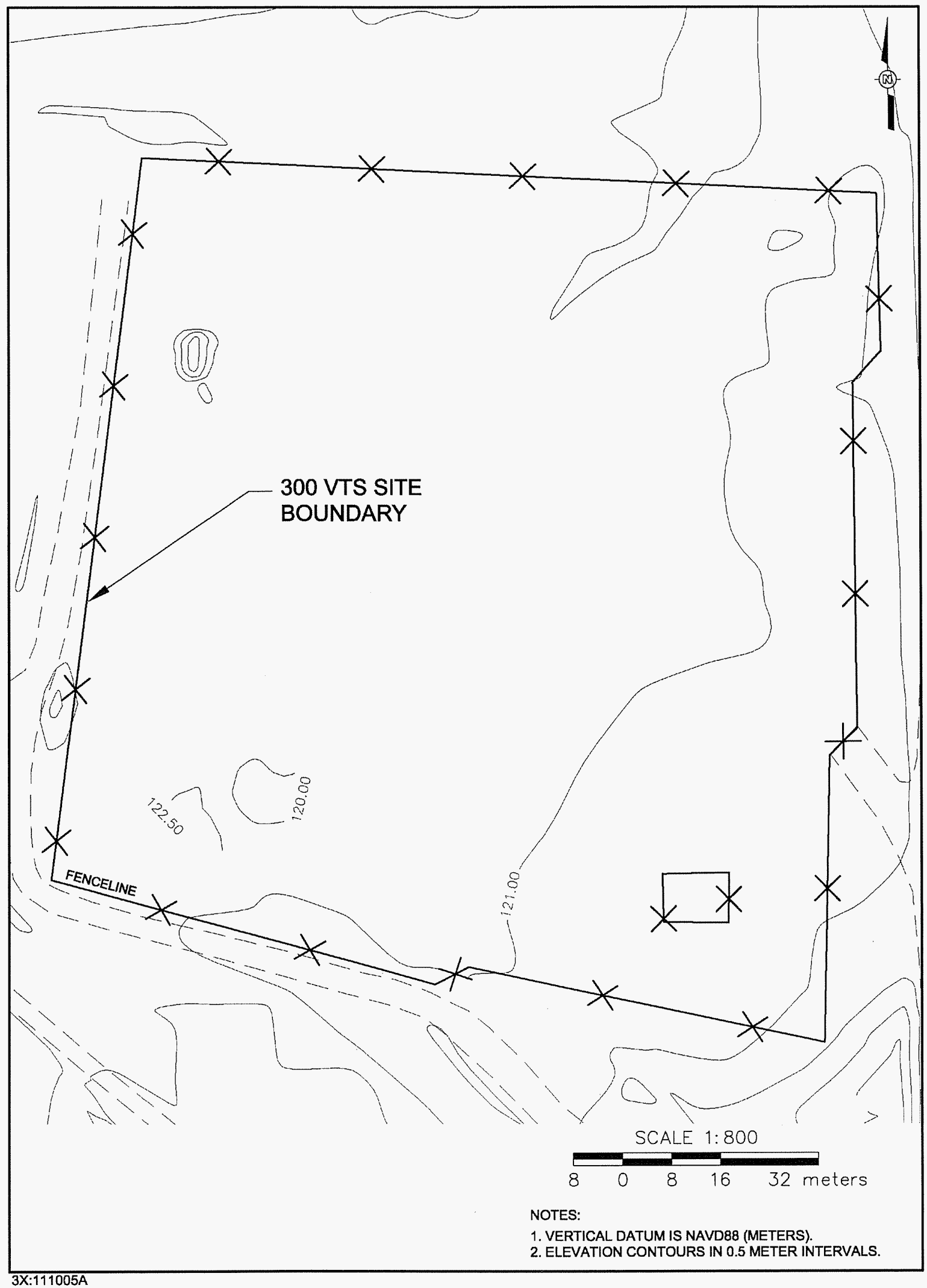


Figure 3. Post-Remediation Topographic Plan for the 300 VTS Site.

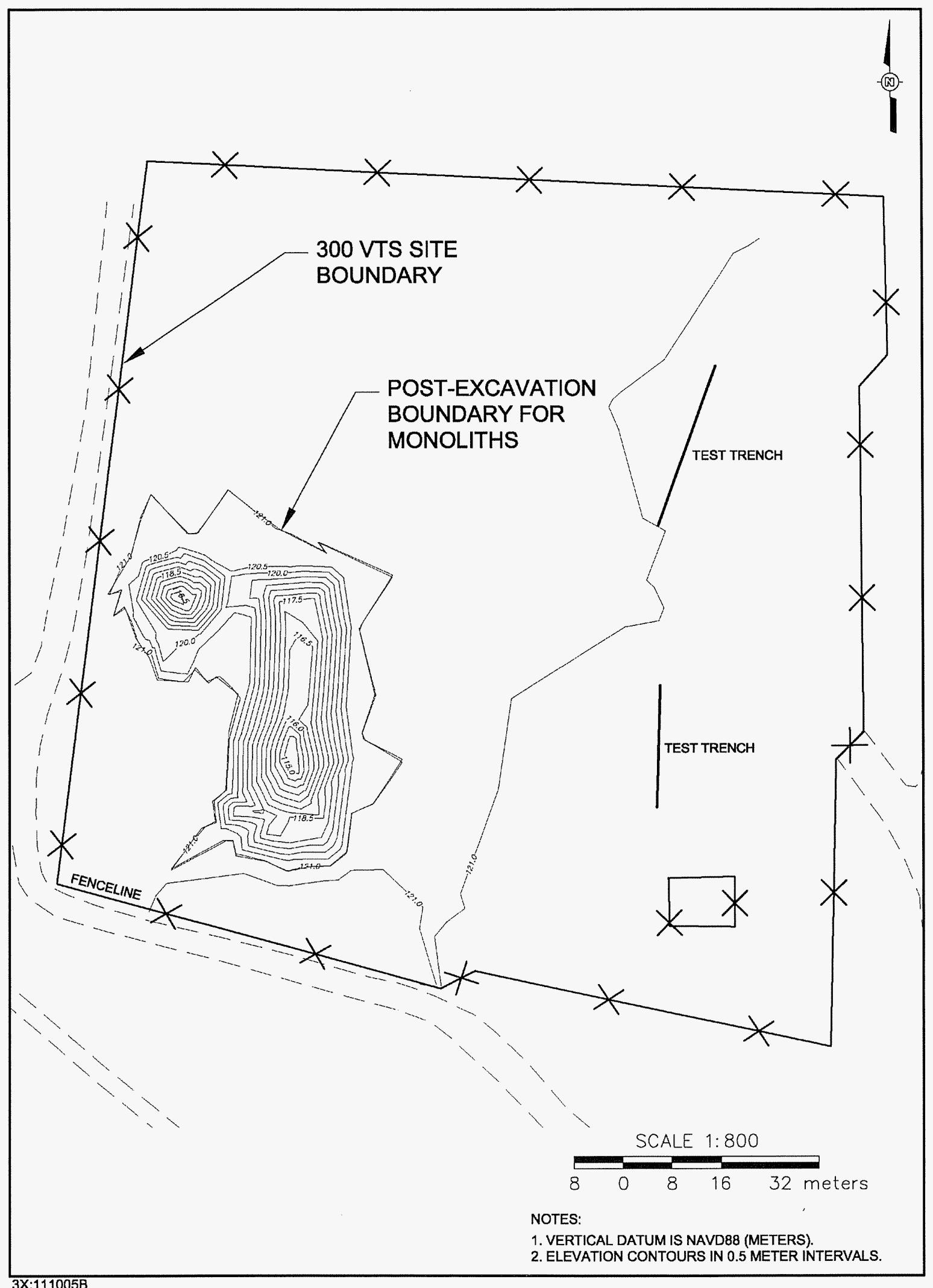


A total of 83 metric tons (91 US tons) of structural steel was recycled from the demolition of the Terra-Vit melter and off-gas hood support structure. Disposal of the off-gas containment structure resulted in 10 metric tons (11 US tons) of material being sent to ERDF. A total of 5,218 metric tons ( 5,752 US tons) of vitrified soil was excavated and sent to Pit 9 for disposal.

\subsection{FIELD SCREENING}

Prior to starting work at the 300 VTS, the Terra-Vit melter and off-gas hood were surveyed by radiological control technicians. No contamination was detected on these structures. An additional gamma spectral survey was performed on the off-gas containment structure; no contamination above background levels was detected.

Following completion of remediation activities, a global positioning environmental radiological survey was performed in the areas where ground disturbances were noted (Figures 4 and 5) and in the excavations where the vitrified monoliths were removed (Figures 6 and 7). The surveys found no contamination. The beta track map (Figure 7) does appear to show two hot spots, but the field crew determined that the two elevated readings were due to a faulty cable. The two "hot spots" were subsequently reevaluated manually with field instruments to confirm no activity above background.

\subsection{BIASED SAMPLING AND ANALYSIS}

Biased samples are typically collected at locations where significant quantities of specific waste streams were unearthed from a common area to help verify the absence of hot spots in the residual soil. At the 300 VTS site, contaminated equipment and test materials were removed by PNNL in the 1980s. Remaining test equipment and uncontaminated buried monoliths were removed as part of the 2005 remedial actions. No containerized liquid was found, and no evidence of historical liquid disposal was identified during the excavation. Consequently, it was determined that radiological surveys and statistical verification sampling would be adequate for site closeout, and biased samples were not collected as per the approved closeout plan (WCH 2005).

\subsection{CLEANUP VERIFICATION SAMPLING AND ANALYSIS}

Final cleanup verification samples were collected on August 22, 2005, to confirm acceptability of residual contaminant concentrations in soil at the 300 VTS site. Based on the overall footprint of the area and depth of excavation, the 300 VTS site was classified as one shallow zone decision unit. The final verification samples were submitted to offsite laboratories for analysis using approved U.S. Environmental Protection Agency analytical methods as described in the SAP (DOE-RL 2004a). 


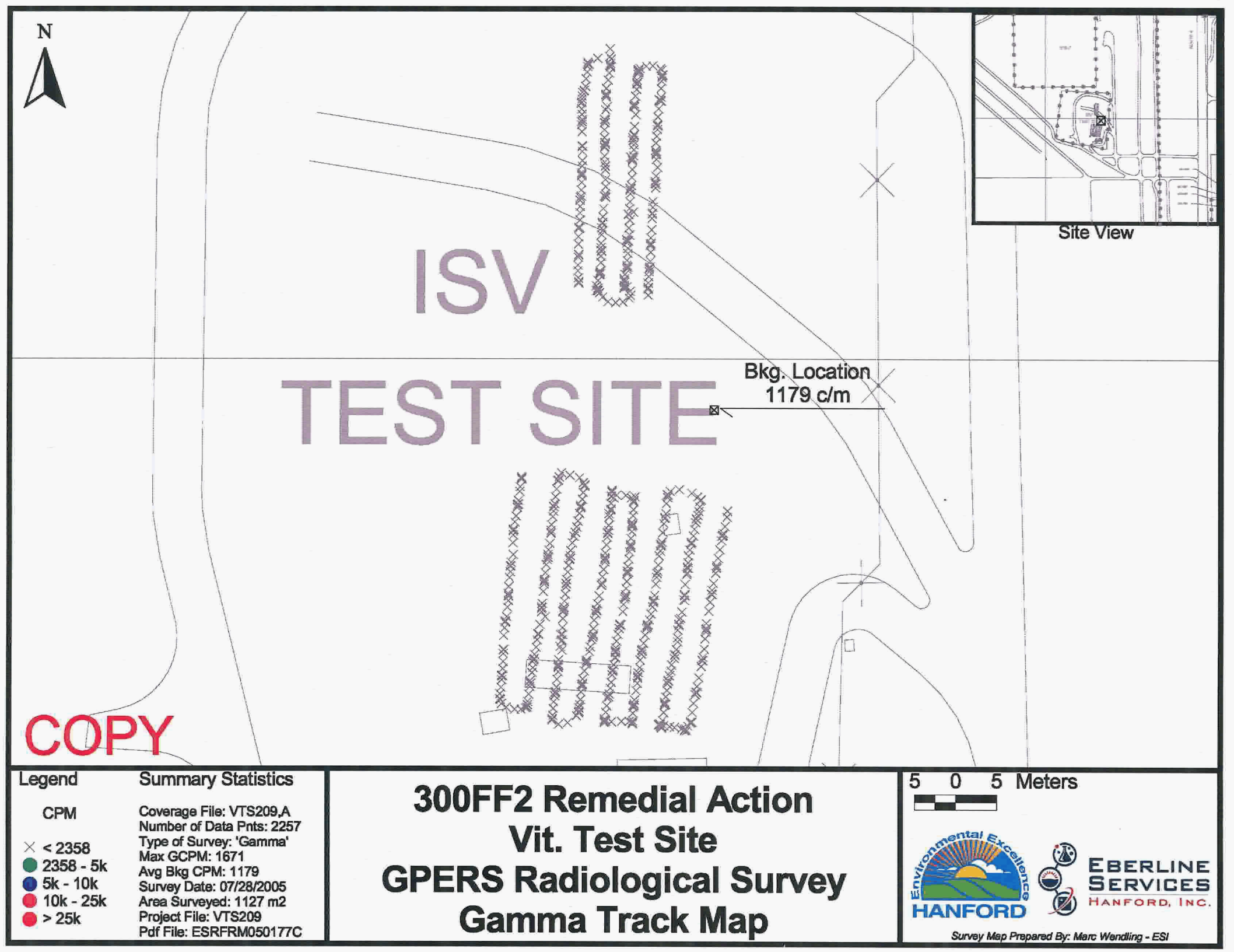

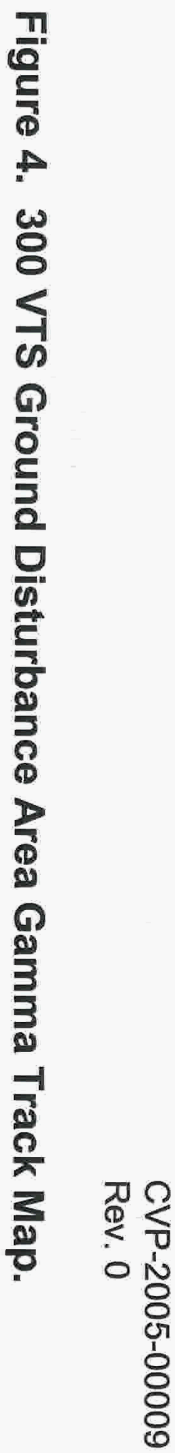




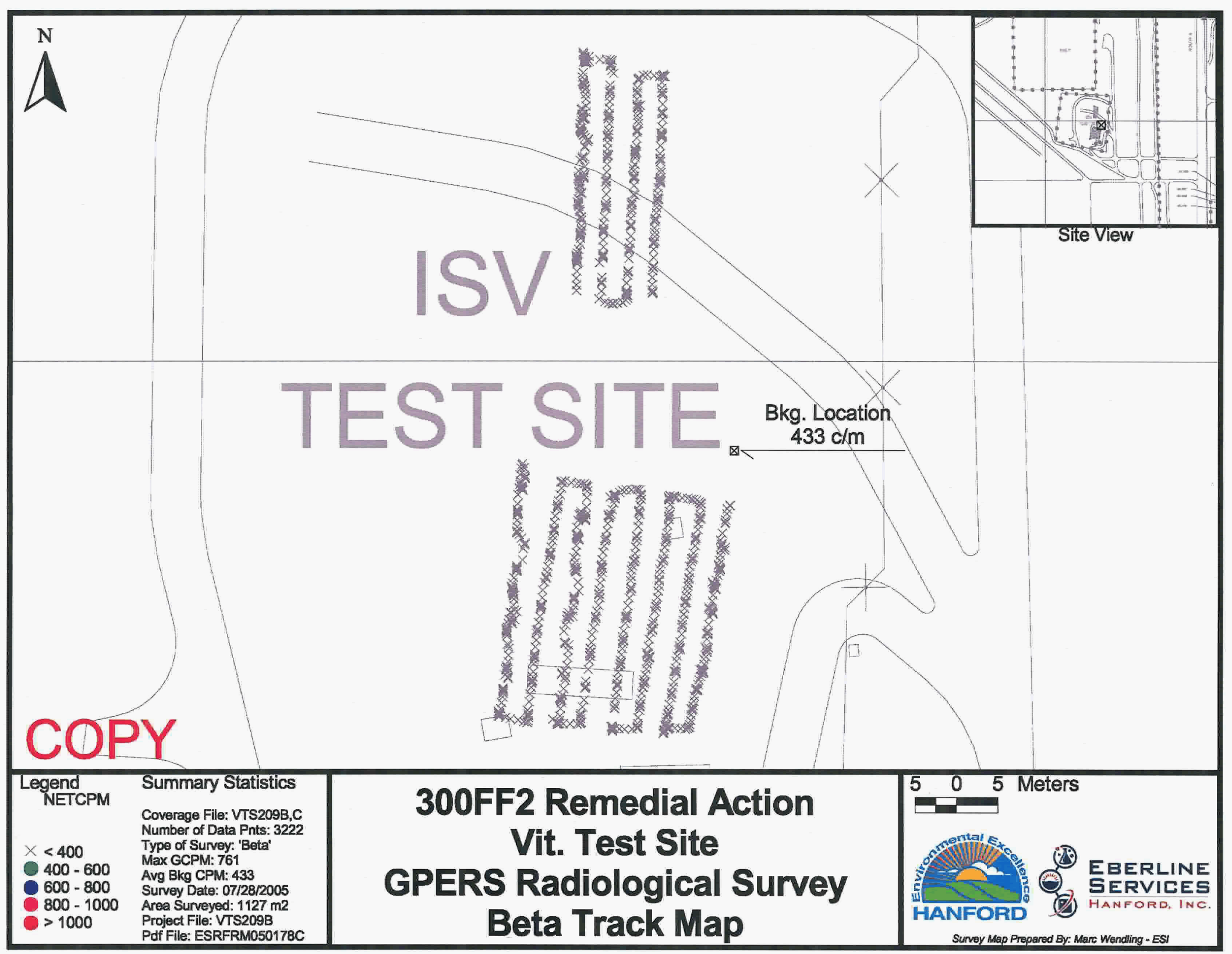

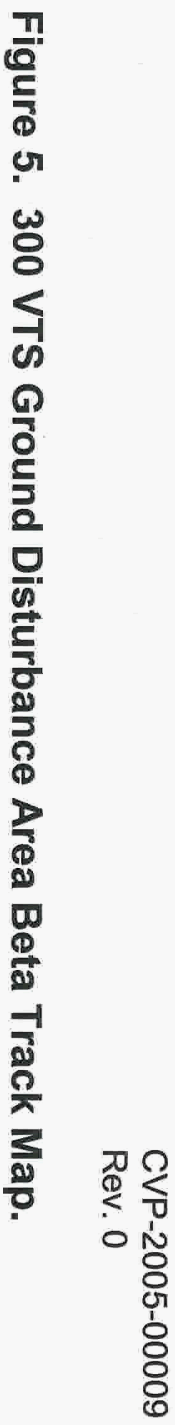




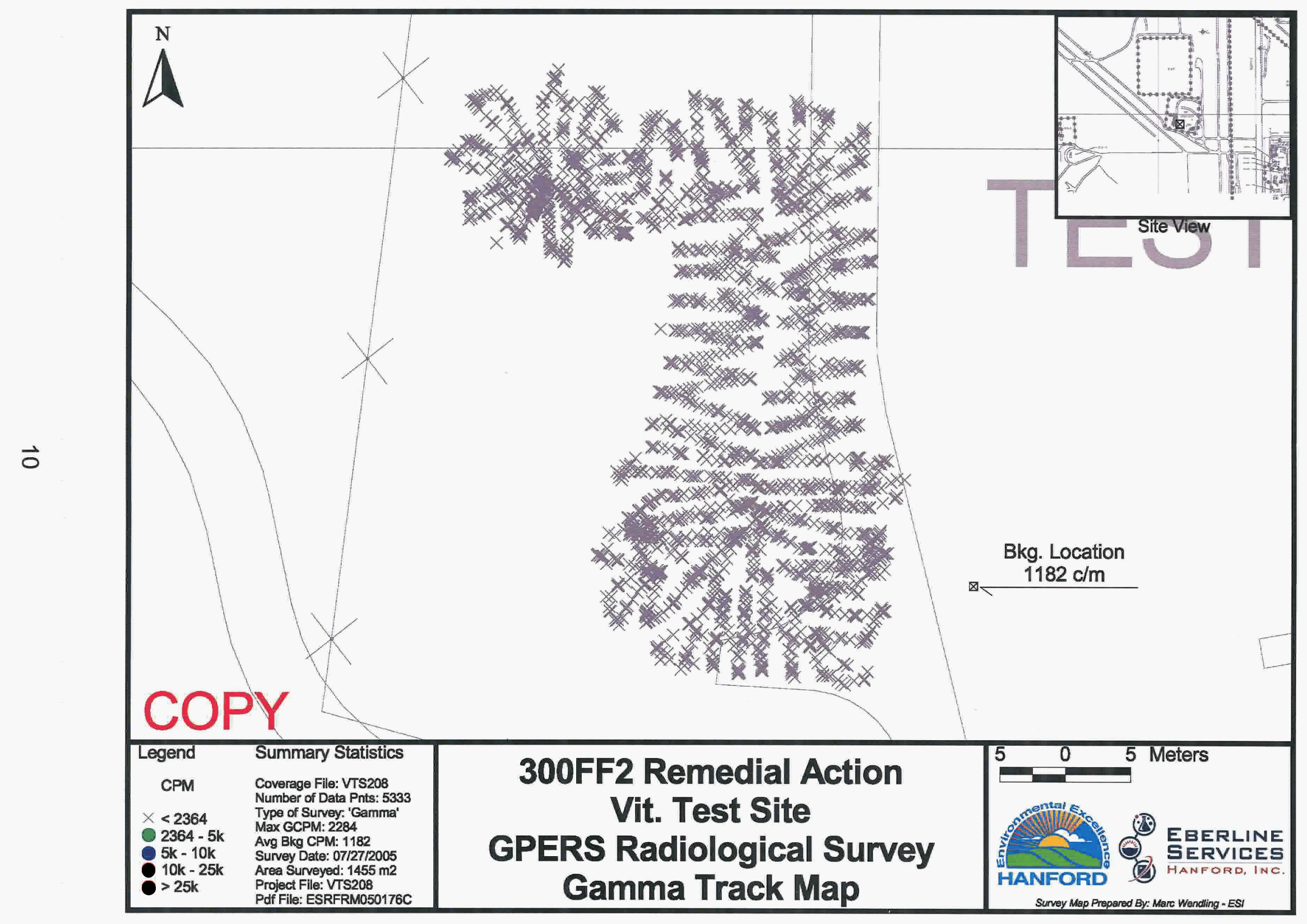

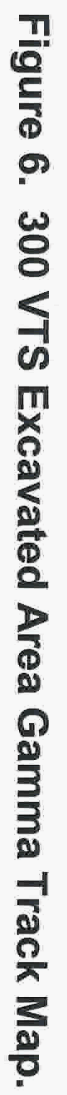




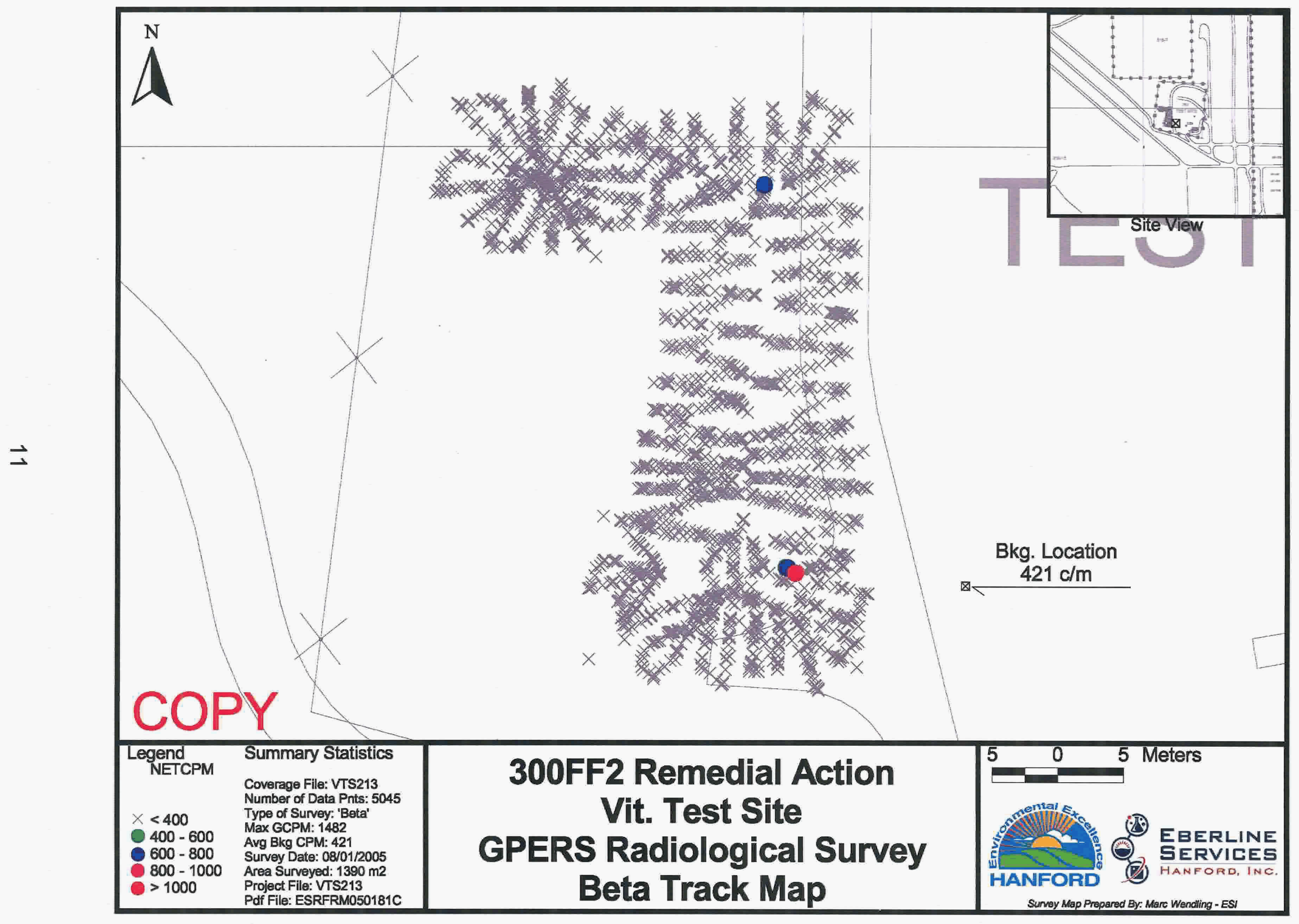

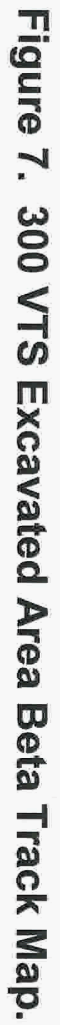


In accordance with the SAP (DOE-RL 2004a), each verification sample was collected as a composite sample formed by combining soil collected at four random locations within the sampling area (excluding the quality assurance/quality control samples). The sample design methodology and sample location figures are presented in the calculation brief for sample design in Appendix C.

\subsection{CLEANUP VERIFICATION DATA EVALUATION}

This section presents the evaluation and modeling of the 300 VTS site cleanup verification data for comparison with the data quality criteria and RAGs.

\subsection{DATA QUALITY ASSESSMENT PROCESS}

A data quality assessment (DQA) is performed to compare the verification sampling approach and resulting analytical data with the sampling and data quality requirements specified by the project objectives and performance specifications.

The DQA for the 300 VTS site determined that the data are of the right type, quality, and quantity to support site verification decisions within specified error tolerances. All analytical data were found to be acceptable for decision-making purposes.

The evaluation also found that the sample design was sufficient to support clean site verification. The cleanup verification sample analytical data are stored in the Hanford Environmental Information System and are summarized in Appendix A. The detailed DQA is presented in Appendix $B$.

\subsection{CONTAMINANTS OF CONCERN 95\% UPPER CONFIDENCE LIMIT}

The primary statistical calculation to support cleanup verification is the $95 \%$ upper confidence limit (UCL) on the arithmetic mean of the data. Prior to calculating the $95 \%$ $\mathrm{UCL}$, the individual sample results are reviewed and, as appropriate, adjusted per the SAP (DOE-RL 2004a). This process is summarized below.

- Radionuclides: The laboratory-reported value is used in the calculation of the $95 \%$ UCL. In cases where the laboratory does not report a value for data qualified with a "U" (i.e., less than the detection limit), half of the minimum detectable activity is used in the calculation of the $95 \% \mathrm{UCL}$.

- Nonradionuclides: For data flagged with a "U" (i.e., less than detection), a value equal to one-half the practical quantitation limit is used in the calculation of the $95 \%$ $\mathrm{UCL}$, as required by Washington State Department of Ecology regulations (WAC 173-340-740[7][g]). If greater than half of the sample results for a given 
nonradionuclide $\mathrm{COC}$ are below detection, the statistical value is set equal to the maximum concentration detected (i.e., versus computing a $95 \% \mathrm{UCL}$ ).

Statistical calculations are presented in the 300 VTS cleanup verification $95 \%$ UCL calculation brief (Appendix C). Verification sampling summary statistics $(95 \% \mathrm{UCL}$ values) are listed in Table 2. The columns on the left side of Table 2 are the COCs and the $95 \%$ UCL values before subtraction of background. The third column of Table 2 presents the background, where values exist. At this site, none of the COCs occur naturally, so this column is labeled "NA" (not applicable). The last column presents the statistical values adjusted for background, which in this case is the same as column 2 $95 \%$ UCL statistical values. This value is the cleanup verification data set used for evaluation against RAGs. None of the COCs for the 300 VTS site were detected in verification samples, with the exception of cesium-137.

\subsection{SITE-SPECIFIC CLEANUP VERIFICATION MODEL}

A site-specific vadose zone model was not developed for the 300 VTS site, as the only COC detected was cesium-137, which is not predicted to migrate to groundwater within 1,000 years based on the generic RESidual RADioactivity (RESRAD) model for the 300 Area (DOE-RL 2004b).

\subsection{RESRAD MODELING}

A site-specific RESRAD model was not developed for the 300 VTS site, as the only radionuclide $\mathrm{COC}$ detected was cesium-137. The statistical residual cesium-137 activity in the cleanup verification data set is below the $15 \mathrm{mrem} / \mathrm{yr}$ dose equivalence direct exposure lookup value (DOE-RL 2004b). 
Table 2. Cleanup Verification Data Set.

\begin{tabular}{|l|c|c|c|}
\hline \multicolumn{1}{|c|}{ COCs } & $\begin{array}{c}\text { Shallow Zone 95\% UCL } \\
\text { Statistical Values }\end{array}$ & $\begin{array}{c}\text { Hanford Site } \\
\text { Background }^{\mathrm{a}}\end{array}$ & $\begin{array}{c}\text { Shallow Zone Cleanup } \\
\text { Verification Data Set }^{\mathrm{b}}\end{array}$ \\
\hline \multicolumn{4}{|c|}{ Radionuclide Concentration $(\mathbf{p C i} / \mathbf{g})^{c}$} \\
\hline Americium-241 & $0.11 \mathrm{U}$ & $\mathrm{NA}$ & $0.11 \mathrm{U}$ \\
\hline Cesium-137 & 0.024 & 1.05 & 0.024 \\
\hline Cobalt-60 & $0.017 \mathrm{U}$ & 0.00842 & $0.017 \mathrm{U}$ \\
\hline Plutonium-238 & $0 \mathrm{U}$ & 0.00378 & $0 \mathrm{U}$ \\
\hline Plutonium-239/240 & $0.067 \mathrm{U}$ & 0.0248 & $0.067 \mathrm{U}$ \\
\hline Ruthenium-106 & $0.13 \mathrm{U}$ & $\mathrm{NA}$ & $0.13 \mathrm{U}$ \\
\hline Strontium-90 & $-0.017 \mathrm{U}$ & 0.178 & $-0.017 \mathrm{U}$ \\
\hline \multicolumn{5}{|c|}{ Nonradionuclide Concentration (mg/kg) } \\
\hline PCBs & \multicolumn{2}{c|}{$\mathrm{NA}$} & $\mathrm{ND}$ \\
\hline
\end{tabular}

NOTE: No COC, with the exception of cesium-137, was detected in any sample.

${ }^{a}$ DOE-RL, 1996, Hanford Site Background: Part 2, Soil Background for Radionuclides, DOE/RL-96-12, Rev. 0, U.S. Department of Energy, Richland Operations Office, Richland, Washington.

${ }^{b}$ For overburden, anthropogenic background (DOE-RL 1996) and naturally occurring background is subtracted from all radionuclides. For other decision units (e.g., shallow zone and deep zone), naturally occurring background (uranium) is subtracted. Refer to the $95 \%$ UCL calculation brief in Appendix C for additional details on determination of statistical values.

${ }^{c}$ Laboratory data, including the minimum detectable activity or practical quantitation limit for the individual cleanup verification samples, are included in Appendix A and the 95\% UCL calculation brief in Appendix C.

COC = contaminant of concern

NA $=$ not applicable

ND $=$ not detected

PCB = polychlorinated biphenyl

$\mathrm{U}=$ undetected

$\mathrm{UCL}=$ upper confidence limit

\subsection{EVALUATION OF REMEDIAL ACTION GOAL ATTAINMENT FOR UNRESTRICTED LAND USE}

This section demonstrates that remedial actions at the 300 VTS site have achieved the applicable RAGs. Cleanup objectives for the 300 VTS site are based on the 300 Area unrestricted land use scenario established in the ESD (EPA 2004).

\subsection{DIRECT EXPOSURE SOIL REMEDIAL ACTION GOALS ATTAINED}

\subsubsection{Radionuclides}

5.1.1.1 Direct Comparison to RAGs. Radionuclide COCs were not detected in statistical cleanup verification samples, with the exception of cesium-137. The statistical activity of cesium-137 is below the $15 \mathrm{mrem} / \mathrm{yr}$ dose equivalence direct 
exposure lookup value of $6.2 \mathrm{pCi} / \mathrm{g}$ (DOE-RL 2004b). No other radionuclide COCs were detected in the samples.

5.1.1.2 Radionuclide Risk. Only cesium-137 was detected in the samples, below the lookup value $(6.2 \mathrm{pCi} / \mathrm{g})$ that satisfies the RAO for cumulative risk $\left(10^{-4}\right.$ to $10^{-6}$ under an unrestricted land-use scenario) (DOE-RL 2004b).

\subsubsection{Nonradionuclides}

5.1.2.1 Direct Comparison to RAGs. No nonradionuclide COCs were detected in the chemical analyses that were performed. Therefore, all applicable RAGs are met.

5.1.2.2 Noncarcinogenic Hazard Quotient. For noncarcinogenic COCs, WAC 173-340-740(5)(a) and (b) specify the evaluation of the hazard quotient, which is given as daily intake divided by a reference dose (DOE-RL 2001). Hazard quotients for nonradionuclide COCs were not calculated because there are no nonradionuclide noncarcinogenic COCs for the 300 VTS site.

5.1.2.3 Carcinogenic Risk. For individual nonradionuclide carcinogenic $\mathrm{COCs}$, the WAC 173-340-750(3) Method B cleanup limits are based on an unrestricted land-use incremental cancer risk of $1 \times 10^{-6}$. The cumulative excess cancer risk for all nonradionuclide carcinogenic COCs must also be less than $1 \times 10^{-5}$ (EPA et al. 1998). The only nonradionuclide carcinogenic COCs at the 300 VTS site were polychlorinated biphenyls, which were not detected in the chemical analyses that were performed. Consequently, excess cancer risk values were not calculated.

\subsection{GROUNDWATER REMEDIAL ACTION GOALS ATTAINED}

\subsubsection{Radionuclides}

Radionuclide COCs were not detected in any cleanup verification samples, with the exception of cesium-137 in the shallow zone sampling. RESRAD modeling predicts that shallow zone cesium-137 will not migrate to groundwater within a 1,000-year period (DOE-RL 2004b).

\subsubsection{Nonradionuclides}

None of the nonradionuclide COCs for the 300 VTS site are predicted to reach groundwater within 1,000 years based on a generic site profile for the 300 Area (DOE-RL 2004b). Further, no nonradionuclide COCs were detected in the chemical analyses that were performed. 


\subsection{COLUMBIA RIVER REMEDIAL ACTION GOALS ATTAINED}

\subsubsection{Radionuclides}

Radionuclide COCs were not detected in any cleanup verification samples, with the exception of cesium-137 in the shallow zone sampling. RESRAD modeling predicts that shallow zone cesium-137 will not migrate to groundwater (and thus the Columbia River) within a 1,000-year period (DOE-RL 2004b).

\subsubsection{Nonradionuclides}

None of the nonradionuclide COCs for the 300 VTS site are predicted to reach groundwater, and thus the Columbia River, within 1,000 years based on a generic site profile for the 300 Area (DOE-RL 2004b). Further, no nonradionuclide COCs were detected in the chemical analyses that were performed.

\subsection{WAC 173-340 THREE-PART TEST FOR NONRADIONUCLIDES}

The WAC 173-340-740(7)(e) three-part test is applicable to nonradionuclide COCs and consists of the following criteria: (1) the cleanup verification statistical value must be less than the cleanup level, (2) no single detection can exceed two times the cleanup criteria, and (3) the percentage of samples exceeding the cleanup criteria must be less than $10 \%$. The most restrictive RAG (defined as the lowest of the direct exposure, groundwater protection, and river protection RAGs) is used for the test.

No nonradionuclide COCs were detected in the chemical analyses that were performed. Consequently, the WAC 173-340-740(e) three-part test was not performed.

\subsection{STATEMENT OF PROTECTIVENESS}

This cleanup verification package demonstrates that remedial action at the 300 VTS site has achieved the RAOs and corresponding RAGs established in the ROD (EPA 2001), the ESD (EPA 2004), and the RDR/RAWP (DOE-RL 2004b). Test equipment and buried monoliths have been demolished or excavated, removed from the site, and recycled or disposed. The remaining soil at the 300 VTS site has been sampled, analyzed, and evaluated. Results indicate that the site supports future land uses that can be represented (or bounded) by the unrestricted land-use scenario and the residual concentrations at the site poses no threat to groundwater or the Columbia River. The site has no deep zone. Consequently, the 300 VTS site is verified to be remediated in accordance with the ROD (EPA 2001) and ESD (EPA 2004) and may be backfilled. 


\subsection{REFERENCES}

65 FR 76708, "National Primary Drinking Water Regulations; Radionuclides; Final Rule," Federal Register, Vol. 65, No. 236, p. 76708, December 7, 2000.

Bergstrom, K. A. and T. H. Mitchell, 2002, Results of Geophysical Investigation Conducted at 618-8 and the 300 VTS Sites, 300 Area, CCN 095617, Interoffice Memorandum to S. E. Parnell dated January 8, 2002, Bechtel Hanford, Inc., Richland, Washington.

BHI, 1994, 300-FF-2 Operable Unit Technical Baseline Report, BHI-00012, Rev. 00, Bechtel Hanford, Inc., Richland, Washington.

BHI, 1999, Facility Endpoint Criteria and Turnover, 300 VTS In-Situ Vitrification (ISV) Test Site, CCN 0517791, October 1999, Bechtel Hanford, Inc., Richland, Washington.

BHI, 2001, Calculation of Total Uranium Activity Corresponding to a Maximum Contaminant Level for Total Uranium of 30 Micrograms per Liter in Groundwater, 0100X-CA-V0038, Rev. 0, Bechtel Hanford, Inc., Richland, Washington.

Comprehensive Environmental Response, Compensation, and Liability Act of 1980, 42 U.S.C. 601 , et seq.

DOE Order 5400.5, Radiation Protection of the Public and the Environment, U.S. Department of Energy, Washington, D.C.

DOE-RL, 1996, Hanford Site Background: Part 2, Soil Background for Radionuclides, DOE/RL-96-12, Rev. 0, U.S. Department of Energy, Richland Operations Office, Richland, Washington.

DOE-RL, 1998, Tri-Party Agreement Handbook Management Procedures, RL-TPA-90-0001, Guideline Number TPA-MP-14, "Maintenance of the Waste Information Data System (WIDS)," U.S. Department of Energy, Richland Operations Office, Richland, Washington.

DOE-RL, 2001, Hanford Site Background: Part 1, Soil Background for Nonradioactive Analytes, DOE/RL-92-24, Rev. 4, U.S. Department of Energy, Richland Operations Office, Richland, Washington.

DOE-RL, 2004a, 300 Area Remedial Action Sampling and Analysis Plan, DOE/RL-2001-48, Rev. 1, U.S. Department of Energy, Richland Operations Office, Richland, Washington. 
DOE-RL, 2004b, Remedial Design Report/Remedial Action Work Plan for the 300 Area, DOE/RL-2001-47, Rev. 1, U.S. Department of Energy, Richland Operations Office, Richland, Washington.

Ecology, EPA, and DOE, 1989, Hanford Federal Facility Agreement and Consent Order, 2 vols., as amended, Washington State Department of Ecology, U.S. Environmental Protection Agency, and U.S. Department of Energy, Olympia, Washington.

EPA, 2001, Record of Decision for the 300-FF-2 Operable Unit, Hanford Site, U.S. Environmental Protection Agency, Region 10, Seattle, Washington.

EPA, 2004, Explanation of Significant Differences for the 300-FF-2 Operable Unit Record of Decision, U.S. Environmental Protection Agency, Region 10, Seattle, Washington.

EPA, Ecology, and RL, 1998, Environmental Restoration Contractor Meeting Minutes Remedial Action and Waste Disposal Unit Managers' Meeting -- 100 Area, Draft, dated July 6, 1998, U.S. Environmental Protection Agency, Washington State Department of Ecology, and U.S. Department of Energy, Richland Operations Office, Richland, Washington.

WAC 173-340, 1996, "Model Toxics Control Act - Cleanup" Washington Administrative Code.

WAC 173-350-410, "Inert Waste Landfills," Washington Administrative Code, as amended.

WCH, 2005, Closeout Plan for the 300 Area VTS, CCN 125659, Washington Closure Hanford, Richland, Washington. 


\section{APPENDIX A}

SUMMARY OF VERIFICATION SOIL SAMPLING AND ANALYTICAL RESULTS 
CVP-2005-00009

Rev. 0 
Table A-1. 300 VTS Shallow Zone Cleanup Verification Data.

\begin{tabular}{|c|c|c|c|c|c|c|c|c|c|c|c|c|c|c|}
\hline \multirow{2}{*}{$\begin{array}{c}\text { Sampling } \\
\text { Area }\end{array}$} & \multirow{2}{*}{$\begin{array}{c}\text { HEIS } \\
\text { Number }\end{array}$} & \multirow{2}{*}{$\begin{array}{c}\text { Sample } \\
\text { Date }\end{array}$} & \multicolumn{3}{|c|}{ Americium-241 } & \multicolumn{3}{|c|}{ Cesium-137 } & \multicolumn{3}{|c|}{ Cobalt-60 } & \multicolumn{3}{|c|}{ Plutonium-238 } \\
\hline & & & $\mathrm{pCi} / \mathrm{g}$ & $\mathbf{Q}$ & MDA & $\mathrm{pCi} / \mathrm{g}$ & $\mathbf{Q}$ & MDA & $\mathrm{pCi} / \mathrm{g}$ & $\mathbf{Q}$ & MDA & $\mathrm{pCi} / \mathrm{g}$ & $\mathbf{Q}$ & MDA \\
\hline $\mathrm{A} 1$ & J03WW7 & $8 / 22 / 05$ & 1.3E-01 & $\mathrm{U}$ & 1.3E-01 & $3.5 \mathrm{E}-02$ & $U$ & $3.5 \mathrm{E}-02$ & $3.9 \mathrm{E}-02$ & $\mathrm{U}$ & $3.9 \mathrm{E}-02$ & 0 & $U$ & 3.7E-01 \\
\hline $\begin{array}{l}\text { Duplicate of } \\
\text { J03WW7 }\end{array}$ & J03WX1 & $8 / 22 / 05$ & 1.7E-01 & U & 1.7E-01 & 3.3E-02 & $U$ & 3.3E-02 & 3.3E-02 & U & 3.3E-02 & 0 & $U$ & 2.8E-01 \\
\hline $\mathrm{A} 2$ & J03WW8 & $8 / 22 / 05$ & 1.4E-01 & $\mathrm{U}$ & $1.4 \mathrm{E}-01$ & $2.5 \mathrm{E}-02$ & $\mathrm{U}$ & $2.5 E-02$ & 2.8E-02 & $\mathrm{U}$ & $2.8 \mathrm{E}-02$ & 0 & $\mathrm{U}$ & 2.5E-01 \\
\hline A3 & J03WW9 & $8 / 22 / 05$ & 2.1E-01 & U & $2.1 \mathrm{E}-01$ & 3.1E-02 & $\mathrm{U}$ & $3.1 \mathrm{E}-02$ & 2.6E-02 & $\mathrm{U}$ & 2.6E-02 & 0 & $U$ & 2.3E-01 \\
\hline A4 & J03WX0 & $8 / 22 / 05$ & 2.2E-01 & $\mathrm{U}$ & 2.2E-01 & $2.9 E-02$ & & 2.7E-02 & $3.2 \mathrm{E}-02$ & $\mathrm{U}$ & $3.2 E-02$ & 0 & $U$ & 2.4E-01 \\
\hline
\end{tabular}

\begin{tabular}{|c|c|c|c|c|c|c|c|c|c|c|c|}
\hline \multirow{2}{*}{$\begin{array}{c}\text { Sampling } \\
\text { Area }\end{array}$} & \multirow{2}{*}{$\begin{array}{c}\text { HEIS } \\
\text { Number }\end{array}$} & \multirow{2}{*}{$\begin{array}{c}\text { Sample } \\
\text { Date }\end{array}$} & \multicolumn{3}{|c|}{ Plutonium-239/240 } & \multicolumn{3}{|c|}{ Ruthenium-106 } & \multicolumn{3}{|c|}{ Strontium-90 } \\
\hline & & & $\mathrm{pCi} / \mathrm{g}$ & $\mathbf{Q}$ & MDA & $\mathrm{pCi} / \mathrm{g}$ & $\mathbf{Q}$ & MDA & $\mathrm{pCi} / \mathrm{g}$ & $\mathbf{Q}$ & MDA \\
\hline A1 & J03WW7 & $8 / 22 / 05$ & 0 & $\mathrm{U}$ & 3.7E-01 & $2.9 \mathrm{E}-01$ & U & $2.9 \mathrm{E}-01$ & $-3.5 E-02$ & $U$ & 2.2E-01 \\
\hline $\begin{array}{c}\text { Duplicate of } \\
\text { J03WW7 }\end{array}$ & J03WX1 & $8 / 22 / 05$ & 3.7E-02 & U & 2.8E-01 & 2.6E-01 & U & 2.6E-01 & $-3.6 E-02$ & $U$ & 2.4E-01 \\
\hline $\mathrm{A} 2$ & J03WW8 & $8 / 22 / 05$ & $9.7 \mathrm{E}-02$ & $\mathrm{U}$ & $2.5 E-01$ & 2.3E-01 & $\mathrm{U}$ & 2.3E-01 & -7.E-03 & $\mathrm{U}$ & 2.8E-01 \\
\hline A3 & J03WW9 & $8 / 22 / 05$ & 0 & U & $2.3 \mathrm{E}-01$ & 2.4E-01 & $U$ & $2.4 \mathrm{E}-01$ & $-3.5 \mathrm{E}-02$ & $\mathrm{U}$ & 2.4E-01 \\
\hline A4 & J03WX0 & $8 / 22 / 05$ & 0 & $\mathrm{U}$ & $2.4 \mathrm{E}-01$ & 2.6E-01 & $U$ & 2.6E-01 & $-4.6 \mathrm{E}-02$ & $\mathrm{U}$ & 2.1E-01 \\
\hline
\end{tabular}

Note: Abbreviations listed below apply to all tables in this appendix.

HEIS = Hanford Environmental Information System

$\mathrm{J}=$ estimate

$\mathrm{MDA}=$ minimum detectable activity

$P Q L=$ practical quantitation limit

$\mathrm{Q}=$ qualifier

$\mathrm{U}=$ undetected 
Table A-2. 300 VTS Polychlorinated Biphenyl Cleanup Verification Data.

\begin{tabular}{|c|c|c|c|c|c|c|c|c|c|c|c|c|c|c|c|}
\hline \multirow[t]{2}{*}{ Constituent } & \multicolumn{3}{|c|}{$\begin{array}{c}\text { J03WW7 } \\
\text { Area A1 } \\
\text { Sample Date 8/22/05 }\end{array}$} & \multicolumn{3}{|c|}{$\begin{array}{c}\text { J03WW8 } \\
\text { Area A2 } \\
\text { Sample Date 8/22/05 }\end{array}$} & \multicolumn{3}{|c|}{$\begin{array}{c}\text { J03WW9 } \\
\text { Area A3 } \\
\text { Sample Date 8/22/05 }\end{array}$} & \multicolumn{3}{|c|}{$\begin{array}{c}\text { J03WX0 } \\
\text { Area A4 } \\
\text { Sample Date 8/22/05 }\end{array}$} & \multicolumn{3}{|c|}{$\begin{array}{c}\text { J03WX1 } \\
\text { Duplicate of J03WW7 } \\
\text { Sample Date } 8 / 22 / 05\end{array}$} \\
\hline & $\mu \mathrm{g} / \mathrm{kg}$ & $\mathbf{Q}$ & PQL & $\mu \mathrm{g} / \mathrm{kg}$ & $\mathbf{Q}$ & PQL & $\mu \mathrm{g} / \mathrm{kg}$ & $\mathbf{Q}$ & PQL & $\mu \mathrm{g} / \mathrm{kg}$ & $\mathbf{Q}$ & PQL & $\mu \mathrm{g} / \mathrm{kg}$ & $\mathbf{Q}$ & PQL \\
\hline Aroclor-1016 & 13 & $U$ & 13 & 13 & $\mathrm{U}$ & 13 & 13 & $U$ & 13 & 13 & $\mathrm{U}$ & 13 & 13 & UJ & 13 \\
\hline Aroclor-1221 & 13 & $U$ & 13 & 13 & $U$ & 13 & 13 & $U$ & 13 & 13 & $U$ & 13 & 13 & UJ & 13 \\
\hline Aroclor-1232 & 13 & $\mathrm{U}$ & 13 & 13 & $U$ & 13 & 13 & $U$ & 13 & 13 & $\mathrm{U}$ & 13 & 13 & UJ & 13 \\
\hline Aroclor-1242 & 13 & $\mathrm{U}$ & 13 & 13 & $U$ & 13 & 13 & $\mathrm{U}$ & 13 & 13 & $\mathrm{U}$ & 13 & 13 & UJ & 13 \\
\hline Aroclor-1248 & 13 & $U$ & 13 & 13 & $\mathrm{U}$ & 13 & 13 & $U$ & 13 & 13 & $U$ & 13 & 13 & UJ & 13 \\
\hline Aroclor-1254 & 13 & $U$ & 13 & 13 & $U$ & 13 & 13 & $\mathrm{U}$ & 13 & 13 & $\mathrm{U}$ & 13 & 13 & UJ & 13 \\
\hline Aroclor-1260 & 13 & $U$ & 13 & 13 & $U$ & 13 & 13 & $U$ & 13 & 13 & $U$ & 13 & 13 & UJ & 13 \\
\hline
\end{tabular}


CVP-2005-00009

Rev. 0

APPENDIX B

DATA QUALITY ASSESSMENT FOR THE 300 VTS WASTE SITE

B-i 
CVP-2005-00009

Rev. 0

B-ii 
CVP-2005-00009

Rev. 0

\section{APPENDIX B}

\section{DATA QUALITY ASSESSMENT FOR THE 300 AREA VITRIFICATION TEST SITE (300 VTS)}

\section{B1.1 OVERVIEW}

This data quality assessment (DQA) was performed to compare the verification sampling approach and resulting analytical data with the sampling and data quality requirements specified by the project objectives and performance specifications. The DQA involves the scientific and statistical evaluation of the data to determine if they are of the right type, quality, and quantity to support their intended use (i.e., closeout decisions [EPA 2000]). The DQA completes the data life cycle (i.e., planning, implementation, and assessment) that was initiated by the data quality objectives process.

This DQA was performed in accordance with WCH-EE-01, Environmental Investigations Procedures. Specific data quality objectives for the site are found in the 300 Area Remedial Action Sampling and Analysis Plan (SAP) (DOE-RL 2004a). The DQA is based on the guidelines presented in Guidance for Data Quality Assessment (EPA 2000). Statistical tests used in this DQA were performed as specified in the SAP and the Remedial Design Report/Remedial Action Work Plan for the 300 Area (RDR/RAWP) (DOE-RL 2004b).

Prior to performing statistical tests, the field logbook (BHI 2005), sample design, and sample analytical data are evaluated for consistency and traceability of the sample data. A portion of the cleanup verification sample analytical data are validated for compliance requirements (DOE-RL 2004b). Data evaluation is performed to determine if the laboratory carried out all steps required by the SAP (DOE-RL 2005a) and the laboratory contract governing the conduct of analysis and reporting of the data. This evaluation also examines the available laboratory data to determine if any analytes are present or absent in the samples and the degree of overall uncertainty associated with that determination. Data validation is done in accordance with validation procedures (BHI 2000a, 2000b) as part of data evaluation. After data evaluation and validation, the appropriate statistical test is performed on the adjusted raw analytical data (see calculation briefs in Appendix C) to determine statistical values for each contaminant. The cleanup verification sample analytical data are stored in the Environmental Restoration project-specific database pending final storage in the Hanford Environmental Information System and are summarized in Appendix A.

\section{B1.2 LABORATORY QUALITY MEASURES}

All verification samples are subject to laboratory-specific quality assurance (QA) requirements, including instrument procurement, maintenance, calibration, and 
operation. Additional laboratory quality control (QC) checks are performed, as appropriate, for the analytical method at a rate of 1 per sample delivery group (SDG), or 1 in 20 , whichever is more frequent. Laboratory internal QC checks include the following:

- Laboratory Contamination. Each analytical batch contains a laboratory (method) blank (material of similar composition as the samples with known/minimal contamination of the analytes of interest) carried through the complete analytical process. The method blank is used to evaluate false-positive results in samples due to contamination during handling at the laboratory.

- Analytical Accuracy. For most analyses, a known quantity of representative analytes of interest (matrix spike [MS]) are added to a separate aliquot of a sample from the analytical batch. The recovery percentage of the added MS is used to evaluate analytical accuracy. For analyses not amenable to MS techniques (e.g., gamma energy analysis) or where analytical recovery is corrected via internal standards (e.g., alpha spectral analyses), accuracy is evaluated from recovery of the QC reference sample (e.g., laboratory control spike or blank spike sample).

- Analytical Precision. Separate aliquots removed from the same sample container (replicate samples) are analyzed for each analytical batch. The replicate sample results (evaluated as relative percent differences [RPDs]) are used to assess analytical precision.

- QC Reference Samples. A QC reference sample is prepared from an independent standard at a concentration other than that used for calibration, but within the calibration range. Reference samples provide an independent check on analytical technique and methodology.

Laboratories are also subject to periodic and random assessments of the laboratory performance, systems, and overall program. These assessments are performed by the Washington Closure Hanford QA group to ensure that the laboratories are performing within laboratory contract requirements.

\section{B1.3 DATA VALIDATION}

After sampling was completed, final laboratory data from SDG H3333 were validated to Level C per WCH-EE-01, Procedure 2.5, "Data Package Validation Process." Level C validation procedures are specified in Data Validation Procedure for Chemical Analysis (BHI 2000a) and Data Validation Procedure for Radiochemical Analysis (BHI 2000b). 
Use of level $\mathrm{C}$ validation procedures was included in the review of the following items, as appropriate, for each analytical method:

- Sample holding times

- Method blanks

- MS recovery

- Surrogate recovery

- MS/matrix spike duplicate results

- Sample replicates

- Associated batch laboratory control sample results

- Achievement of required (or contractual) detection limits (RDLs)

- Data package completeness.

The adequacy of laboratory $\mathrm{QA} / \mathrm{QC}$ was evaluated for precision, accuracy, completeness, and RDLs pursuant to the SAP (DOE-RL 2004a). The organization performing the data validation reported that, of the data given formal validation, the laboratory met the standards for performance for precision $( \pm 30 \%)$, accuracy $( \pm 30 \%)$, and completeness $(>90 \%)$. Comparison of the RDL with the respective minimum detectable activity or practical quantitation limit is discussed in Section B1.4.

The validation process did not identify any major deficiencies for the sample results. A minor deficiency was identified in the polychlorinated biphenyl analysis for sample J03WX1. The sample had low surrogate recoveries and has been qualified as estimated with a " $\mathrm{J}$ " flag. Additional information is provided in the associated validation reports (WCH 2005a, 2005b).

\section{B1.4 DATA EVALUATION}

The context for assessing the data includes evaluating the sample data using the statistical methodology of the SAP (DOE-RL 2004a) (included in the calculation brief excerpts in Appendix C) and a comparison of analytical results to the parameters as specified in the SAP. This section summarizes the results of the comparison and presents an evaluation of the affected data.

\section{B1.4.1 RDL Comparison}

Reported analytical detection levels for nondetected analytes were compared to the RDLs specified in the SAP (DOE-RL 2005a). When detected results are obtained, evaluation of detection limits is not performed. The data validation and supplemental data evaluation noted no analyses for which the detection limit (minimum detectable activity or practical quantitation limit) was above SAP RDLs for nondetected analytes.

\section{B1.4.2 Precision and Accuracy Evaluation}

Analytical accuracy and precision were evaluated by examination of the percent recovery and RPD of analytical spikes (MS and/or laboratory control sample) between 
the main and duplicate samples. Only the contaminants of concern (COCs) detected at five times the detection limit (or greater) are used for data analysis with respect to accuracy and precision. The RPDs for all laboratory duplicates and the recoveries for all laboratory spikes were within acceptable limits.

\section{B1.5 FIELD QUALITY ASSURANCE/QUALITY CONTROL}

Field QA/QC measures were used to assess potential sources of error and crosscontamination of soil samples that could bias results. Field QA/QC samples included the following:

- Duplicate J03WX1, associated with sample J03WW7

- Split J03WX2, associated with sample J03WW7.

All main and QA/QC sample results are presented in Appendix A.

\section{B1.5.1 Field Duplicate Samples}

Duplicate samples were collected to provide a relative measure of the degree of local heterogeneity in the sampling medium, unlike laboratory duplicates that are used to evaluate precision in the analytical process. The field duplicates are evaluated by computing the RPD of the duplicate samples for each COC. Only analytes with values above five times the contractual RDLs for both the main and duplicate samples are compared. Based on these criteria, RPD analysis was not required for any duplicate pairs. The $95 \%$ upper confidence limit calculation brief in Appendix $\mathrm{C}$ provides details on duplicate pair evaluation and RPD calculation.

\section{B1.5.2 Field Split Samples}

Split samples were collected to provide a relative measure of the degree of variability in the sampling, sample handling, and analytical techniques used by commercial laboratories. The field main and split samples are evaluated by computing the RPD of the split samples for each $\mathrm{COC}$ to determine the usability of the verification data. The U.S. Environmental Protection Agency Contract Laboratory Program duplicate sample comparison methodology, USEPA Contract Laboratory Program National Functional Guidelines for Inorganic Data Review (EPA 1994), is used as an initial test of the data from the splits. Only analytes that had values above five times the contractual RDL for both the main and split sample were compared. Based on these criteria, RPD analysis was not required for any split pairs. The $95 \%$ upper confidence limit calculation brief in Appendix $\mathrm{C}$ provides details on split pair evaluation and RPD calculation. 


\section{B1.6 SUITABILITY OF DATA}

The DQA for the 300 VTS site determined that the data are of the right type, quality, and quantity to support site cleanup verification decisions within specified error tolerances. The evaluation verified that the sample design was sufficient for the purpose of clean site verification. All analytical data were found to be acceptable for decision-making purposes, and the raw data are acceptable for calculating the required statistical values.

\section{B2.0 REFERENCES}

BHI, 2000a, Data Validation Procedure for Chemical Analysis, BHI-01435, Rev. 0, Bechtel Hanford, Inc., Richland, Washington.

BHI, 2000b, Data Validation Procedure for Radiochemical Analysis, BHI-01433, Rev. 0, Bechtel Hanford, Inc., Richland, Washington.

BHI, 2005, 300-FF-2 Analytical Field Services, Logbook EL-1395-11, Bechtel Hanford, Inc., Richland, Washington.

DOE-RL, 2004a, 300 Area Remedial Action Sampling and Analysis Plan, DOE/RL-2001-48, Rev. 1, U.S. Department of Energy, Richland Operations Office, Richland, Washington.

DOE-RL, 2004b, Remedial Design Report/Remedial Action Work Plan for the 300 Area, DOE/RL-2001-47, Rev. 1, U.S. Department of Energy, Richland Operations Office, Richland, Washington.

EPA, 1994, USEPA Contract Laboratory Program National Functional Guidelines for Inorganic Data Review, EPA 540/R-94/013, U.S. Environmental Protection Agency, Washington, D.C.

EPA, 2000, Guidance for Data Quality Assessment, EPA QA/G-9, QA00 Update, U.S. Environmental Protection Agency, Office of Environmental Information, Washington, D.C.

WCH, 2005a, Data Validation Package - PCB (SDG No. H3333), Washington Closure Hanford, Richland, Washington.

WCH, 2005b, Data Validation Package - Radiochemistry (SDG No. H3333), Washington Closure Hanford, Richland, Washington.

WCH-EE-01, Environmental Investigations Procedures, Washington Closure Hanford, Richland, Washington. 
CVP-2005-00009

Rev. 0

B-6 
CVP-2005-00009

Rev. 0

APPENDIX C

CALCULATION BRIEF EXCERPTS

C-i 
CVP-2005-00009

Rev. 0

\section{DISCLAIMER FOR CALCULATIONS}

The attached calculations have been generated for a specific purpose and task. Use of these calculations by persons who do not have access to all pertinent facts may lead to incorrect conclusions and/or results. Before applying these calculations to your work, the underlying basis, rationale, and other pertinent information relevant to these calculations must be thoroughly reviewed with appropriate Washington Closure Hanford officials or other authorized personnel. Washington Closure Hanford is not responsible for the use of a calculation not under its direct control. 


\section{CALCULATION BRIEFS}

The following calculation briefs have been prepared in accordance with WCH-DE-01, Design Engineering Procedures Manual, EDPI-4.37-01, "Project Calculations," Washington Closure Hanford, Richland, Washington.

300 VTS Site Shallow Zone Sampling Plan, 0300X-CA-V0060, Rev. 1, Washington Closure Hanford, Richland, Washington.

300 VTS Cleanup Verification 95\% UCL Calculation, 0300X-CA-V0059, Rev. 0, Washington Closure Hanford, Richland, Washington.

NOTE: The calculation briefs referenced in this appendix are kept in the active Washington Closure Hanford project files and are available upon request. When the project is completed, the files will be stored in a U.S. Department of Energy, Richland Operations Office repository. Only excerpts of the calculation briefs are included in this appendix. 
CVP-2005-00009

Rev. 0

C-2 
CVP-2005-00009

Rev. 0

\section{CALCULATION COVER SHEET}

Project Title:

Area

Discipline

Subject

Computer Program
300 VTS Site Sample Design

300 Area

Environmental Engineering

300 VTS Site Shallow Zone Sampling Plan
Job No.

14655 Excel

Program No. Excel 2003

The attached calculations have been generated to document compliance with established cleanup levels. These documents should be used in conjuction with other relevent documents in the administrative record.

Committed Calculation $\square \quad$ Preliminary $\square \quad$ Superseded $\square \quad$ Voided $\square$

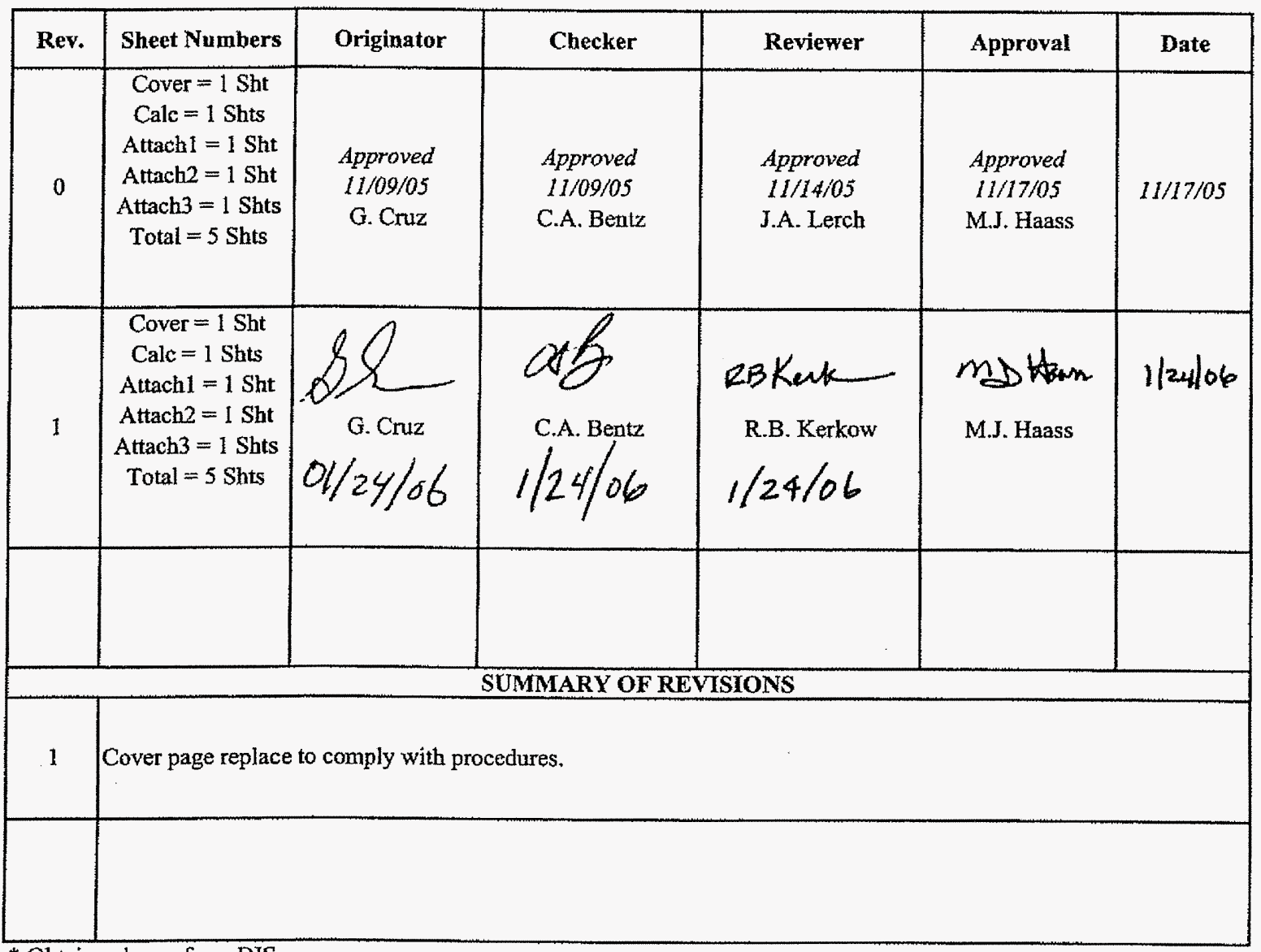

\footnotetext{
* Obtain calc no. from DIS
}

DE01437.03 (12/09/2004) 


\section{Washington Closure Hanford}

Originator

Project

Subject

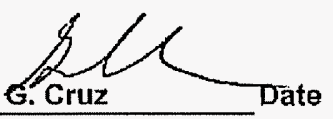

Date 11/9/2005 300 VTS Site Sample Design 300 VTS Site Shallow Zone Sampling Plan
Calc. No. 0300X-CA-V0060 Job No. 14655

Checked Rev. No. 0 cob Date $11 / 09 / 05$ Sheet No 1 of 1

\section{ATTACHMENT 1}

${ }_{3}$ Sample Grid Point Lookup Table.

4

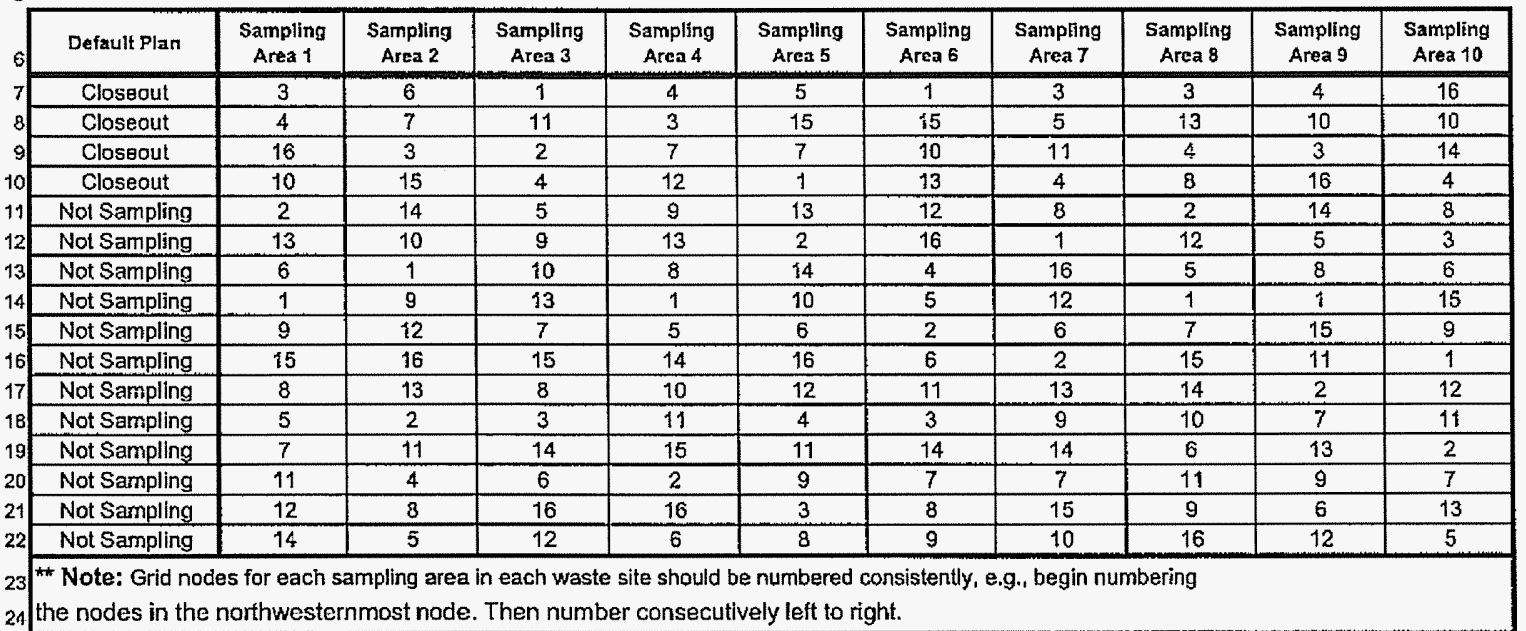

24 the nodes in the northwesternmost node. Then number consecutively left to right. 
CVP-2005-00009

Rev. 0

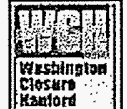

Washington Clgsure Hanford

Originator G. Cruz

Date $11 / 9 / 2005$

Calc. No. 0300X-CA-V0060

Rev. No. 0

Project 300 VTS Site Sample Design Job No. 14655 Checked Cs 6 Date $1 / 109 / 05$

Subject 300 VTS Site Shallow Zone Sampling Plan Sheet No. 1of1

\begin{tabular}{|c|c|c|c|c|c|c|}
\hline \multicolumn{7}{|c|}{${ }_{3}$ Number of Decision Subunits Based on Area. } \\
\hline 8 & \multicolumn{6}{|c|}{ Site Verification Sampling Frequencies Based on Area. } \\
\hline 9 & Decision Unit ${ }^{2}$ & Waste Site Size & $\begin{array}{l}\text { Decision } \\
\text { Subunits } \\
\end{array}$ & Blocks $^{c}$ & $\begin{array}{l}\text { Discrete } \\
\text { Samples }\end{array}$ & $\begin{array}{c}\text { Composite } \\
\text { Samples }\end{array}$ \\
\hline & \multirow{3}{*}{$\begin{array}{l}\text { Shallow zone - } \\
01015 \mathrm{ft}\end{array}$} & Small: $<100,000 \mathrm{ft}^{2}$ & 1 & 4 & 16 & 4 \\
\hline & & Medium: $>100,000 \mathrm{ft}^{2}<400,000 \mathrm{ft}^{2}$ & 4 & 16 & 64 & 16 \\
\hline & & Large: $>400.000 \mathrm{ft}^{2}$ & 8 & 32 & 128 & 32 \\
\hline 14 & \multirow{3}{*}{$\begin{array}{l}\text { Deep Zone - } \\
>15 \mathrm{ft}\end{array}$} & Small: $<100.000 \mathrm{ft}^{2}$ & 1 & 4 & 16 & 4 \\
\hline & & Medium: $>100.000 \mathrm{ft}^{2}<400.000 \mathrm{ft}^{2}$ & 4 & 16 & 64 & 16 \\
\hline & & Large: $>400.000 \mathrm{ft}^{2}$ & 8 & 32 & 128 & 32 \\
\hline & \multirow{3}{*}{$\begin{array}{l}\text { Overburen/layback } \\
\text { stockpiles }\end{array}$} & Small: $<100,000 \mathrm{ft}^{2}$ & 1 & 4 & 16 & 4 \\
\hline & & Medium: $>100,000 \mathrm{ft}^{2}<400,000 \mathrm{ft}^{2}$ & 4 & 16 & 64 & 16 \\
\hline 19 & & Large: $>400,000 \mathrm{ft}^{2}$ & 8 & 32 & 128 & 32 \\
\hline & \multirow{3}{*}{$\begin{array}{l}\text { Staging pile areas } \\
\text { (residual soil) }\end{array}$} & Small: $<100.000 \mathrm{ft}^{2}$ & 1 & 4 & 16 & 4 \\
\hline & & Medium: $>100.000 \mathrm{ft}^{2}<400,000 \mathrm{ft}^{2}$ & 4 & 16 & 64 & 16 \\
\hline & & Latge: $>400,000 \mathrm{ft}^{2}$ & 8 & 32 & 128 & 32 \\
\hline
\end{tabular}

- The shallow zone, deep zone, overburden stockpise, and staging pile areas cach represent single decision units. The total number of decision

units will vary because individual waste sites may not have a deep zone, overburden stockpilc, and/or staging pile areas.

- Arca of exposed surface after excavation or area of stockpilc basc (as applicable)

c Decision su'annits are divided into four blocks to ensure that random sampling locations are not buncined together in one area 
CVP-2005-00009

Rev. 0

C-6 


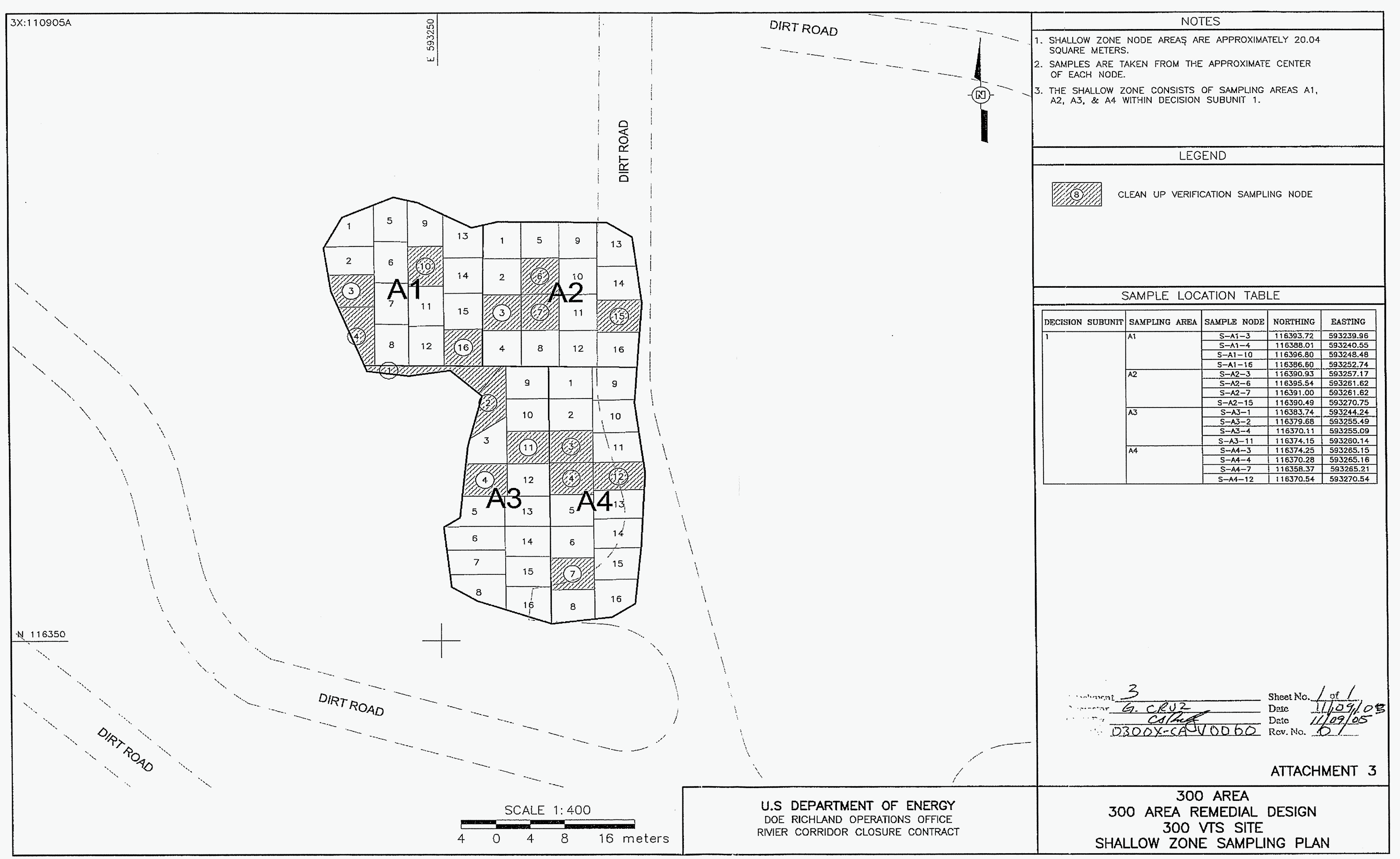


CVP-2005-00009

Rev. 0

\section{CALCULATION COVER SHEET}

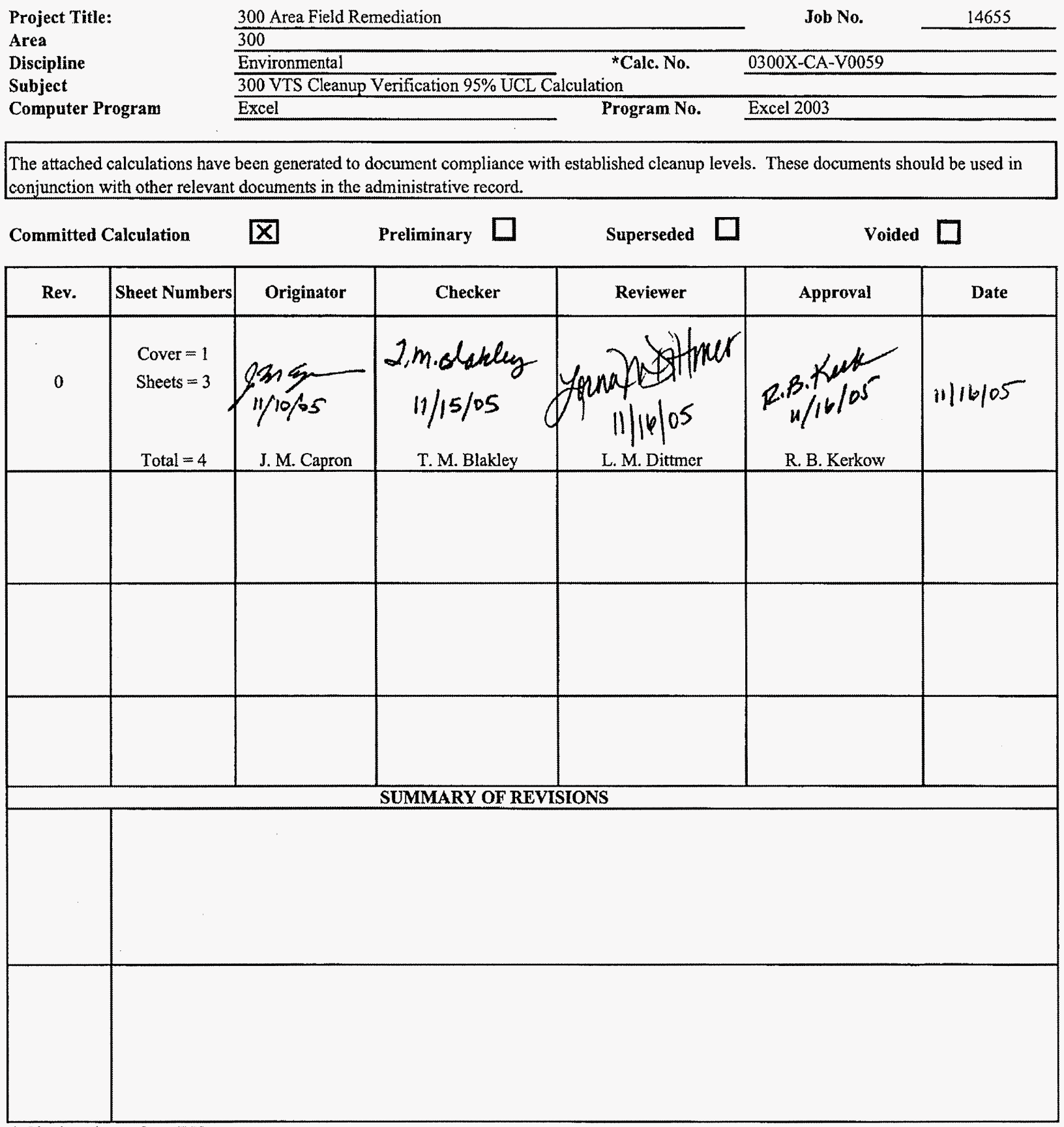

* Obtain calc no. from DIS

DE01437.03 (12/09/2004) 


\section{Washington Closure Hanford

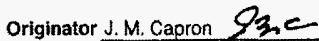 \\ Project 300 Area Fiel Remediation \\ Originator J.M. Capron $Q 3, c$ Subject 300 VTS Cleanup Verification $95 \%$ UCL Caculation}

\section{CALCULATION SHEET}

Date $11 / 10 / 05$

Job No. $\overline{14655}$
Cale. No. $0300 \mathrm{X}$-CA. $\mathrm{V} 0059$

Checked T.M. Blakley $\ln B$

Rev. No. $\frac{0}{\text { Date } 11 / 15 / 05}$
Sheet No. $\frac{1 \text { of } 3}{}$

Purpose:

Calculate the $95 \%$ upper confidence limit (UCL) to evaluate compliance with cleanup standards for the subject site. Also, calculate the relative percent difference (RPD). as necessary, for each contaminant of potential concern (COPC).

2) Lookup values, background values, and remedial action goals (RAGs) are taken from DOE-RL (1996), the remedial design report/remedial action work plan (RDR/RAWP) (DOE-RL 2004b), and Ecology (1996).

3) DOE-RL, 1996, Hantord Site Background: Part 2, Soil Background for Radionuclides, DOE/RL-96-12, Rev. 0, U.S. Department of Energy, Richland Operations Office, Pichland, Washington.

4) DOE-RL, 2004a, 300 Area Remedial Action Sampling and Analysis Plan, DOE/RL-2001-48, Rev. 1, U.S. Department of Energy, Richland Operations Office, Fichland, Washington.

5) DOE-RL, 2004b, Remedial Design Report/Remedial Action Work Plan for the 300 Area, DOE/RL-2001 -47, Rev. 1, U.S. Department of Energy, Richland Operations Office, Fichland, Washington.

6) Ecology, 1992, Statistical Guidance for Ecology Site Managers, Publication \#92-54, Washington State Department of Ecology, Olympia, Washington.

7) Ecology, 1993, Statistical Guidance for Ecology Site Managers, Supplement S-6, Analyzing Site or Background Data with Below-Detection Limit or Below-PQL Values (Censored Data Sets), Publication \#92-54, Washington State Department of Ecology, Olympia, Washington.

8) Ecology, 1996, Model Toxics Control Act Cleanup Levels and Risk Calculations (CLARC II), Publication \#94-145, Washington State Department of Ecology, Olympia, Washington.

9) EPA, 1994, USEPA Contract Laboratory Program National Functional Guidelines for Inorganic Data Review, EPA 540/R-94/013, U.S. Environmental Protection Agency, Washington, D.C.

10) WAC 173-340, 1996, "Model Toxics Control Act--Cleanup," Washington Administrative Code.

Solution:

Calculation methodology is described in Ecology Pub. \#92-54 (Ecology 1992, 1993), below, and in the RDR/RAWP (DOE-RL 2004b). Use data from aftached worksheets to calculate the $95 \%$ UCL and the RPD for each analyte and lo perform the WAC 173-340 3-part test for nonradionuclides.

Calculation Description:

The subject calculations were performed on data from soil verification samples from waste site $300 \mathrm{VTS}$. The data were entered into an EXCEL 2003 spreadsheet and calculations performed by utilizing the built-in spreadsheet functions and/or creating formulae within the cells. The statistical evaluation of data for use in accordance with the ADR/RAWP (DOE-RL 2004b) is documented by this calculation. Split and duplicate RPD results are used in evaluation of data quality and are presented in the cleanup veritication package (CVP) for this site.

Methodology:

The statistical value calculated to evaluate the effectiveness of cleanup was the $95 \%$ UCL. For nonradioactive analytes with $>50 \%$ of the data below detection limits, the maximum value for the sample data is used instead of the $95 \% \mathrm{UCL}$. All nonradionuclide data reported as being below detection limits are set to $1 / 2$ the detection limit value for calculation of the statistics (Ecology 1993). The only nonradionuclide COPCs identified for the 300 VTS site were polychlorinated biphenyls, which were not derers 1 For For radionuclide data, calculation of the statistics was done on the reported value. In cases where the laboratory does not report a value below the minimal detectable activity (MDA), half of the MDA is used in the calculation.

For the statistical evaluation of duplicate sample pairs, the samples are averaged before being included in the data set, after adjustments for censored data as described above.

For nonradionuclides, the WAC 173-340 statistical guidance suggests that a test for distributional form be performed on the data, and the $95 \%$ UCL calculated on the appropriate distribution using Ecology software. For nonradionuclide small data sets $(n<10)$ and all radionuclide data sets, the calculations are performed assuming nonparametric distribution, so no test for distribution is performed. For nonradionuclide data sets of ten or greater, distributional testing is done using Ecology's MTCAStat software (Ecology 1993).

The WAC 173-340 3-part test is performed for nonradionuclide analytes only; no nonradionuclide COPCs were detected at the 300 VTS waste site.

The RPD is calculated when both the main value and either the duplicate or split values are above detection limits and are greater than 5 times the target detection limit (TDL). The TDL is a laboratory detection limit pre-determined for each analytical method. These detection limit requirements are listed in Table 2-1 of the sampling and analysis plan (DOE-RL 2004a). The RPD calculations use the following formula: $R P D=[|M-S| /(M+S) / 2)]^{*} 100$

\section{where, $M=$ Main Sample Value $\quad S=$ Split (or duplicate) Sample Value}

For quality assurance/quality control (QAQC) split and duplicate RPD calculations, a value less than $+/-30 \%$ indicates the data compare favorably. For regulatory splits, a threshold of $+/-35 \%$ is used (EPA 1994). If the RPD is greater than $+/-30 \%($ or $+/-35 \%$ for regulatory split data), further investigation regarding the usability of the data is performed. Additional discussion as necessary is provided in the data quality assessment section of the applicable CVP.

If regulator split comparison is required, an additional parameter is evaluated. A control limit of $+1-2$ times the TDL shall be used if either the main or regulator splt value is less than 5 times the TDL and above detection. In the case where only one result is greater than 5 times the TDL and the other is below, the $+/ .2$ times the TDL criteria applies. Therefore, the following calculation is performed as part of the evaluation for these two cases involving regulator split data: difference $=$ main - regulator split. If the difference is greater than $+1-2$ times the TDL, then further investigation regarding the usability of the data is performed and presented in the applicable CVP data quality assessment section.

No regulatory split samples were collected at the $300 \mathrm{VTS}$ site. 
CVP-2005-00009

Rev. 0

Washington Closure Hanford

CALCULATION SHEET

Originator J.M. Capron $q$ anc

Job No. 14655

Job

Calc. No. 0300X-CA-V0059

Checked T.M. Blakley $\operatorname{mB}$

Rev. No.

Summary (continued)

1 Results:

2 The results presented in the summary tables that follow are for use in RESRAD dose/risk analysis and the CVP for this site.

4 Results Summary-Shallow Zone

\begin{tabular}{|c|c|c|c|}
\hline Analyte & Result & Quallfier & Units \\
\hline Americium-241 & $1.1 E-01$ & $U$ & $\mathrm{pClig}$ \\
\hline Cesium-137 & $2.4 E-02$ & & pCilg \\
\hline Cobalt -60 & $1.7 E-02$ & $\mathrm{U}$ & pCilg \\
\hline Plutonium-238 & & $\bar{U}$ & $\mathrm{pCi} / \mathrm{g}$ \\
\hline Plutonium-239/240 & $6.7 E-02$ & U & $\mathrm{pCilg}$ \\
\hline Ruthenium-106 & $1.3 \mathrm{E}-01$ & 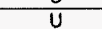 & $\mathrm{pCilg}$ \\
\hline Strontium- 90 & $-1.7 E-02$ & $\bar{u}$ & pcilg \\
\hline
\end{tabular}

Strontium-90

Relative Percent Difference (RPD)

Results (Shallow Zone)* QAVCC Analysis

\begin{tabular}{l|c|c|c|}
16 & Analyte & $\begin{array}{c}\text { Duplicate } \\
\text { Analysis }\end{array}$ & $\begin{array}{c}\text { Split } \\
\text { Analysis }\end{array}$ \\
\cline { 2 - 4 } & &
\end{tabular}

18 Cosium-137

19 Coball-60

20 Plutonium-238

Plutonium-239/240

Ruthenium-106

Strontium-90

"A blank cell indicates that RPD evaluation was not required

$25 \mathrm{CVP}=$ cleanup verification package

$26 \quad \mathrm{QAQC}=$ quality assurance/quality control

RESRAD = RESidual RADioactivity \{dose model)

$28 \mathrm{U}=$ undetected

29 
CVP-2005-00009

Rev. 0

C-12 


\section{Washington Closure Hanford}

Originator J. M. Capron qme

Subject 300 VTS Cleanup Verification $95 \%$ UCL Calculation

Date $\frac{11 / 10 / 05}{14655}$
Job No.

CALCULATION SHEET

hallow Zone Sample Data

\begin{tabular}{|c|c|c|c|c|c|c|c|c|c|c|c|c|c|c|c|c|c|c|c|c|c|c|c|}
\hline \multirow{2}{*}{$\begin{array}{c}\text { Sampling } \\
\text { Area }\end{array}$} & \multirow{2}{*}{$\begin{array}{l}\text { HEIS } \\
\text { Number } \\
\text { J03wW7 }\end{array}$} & \multirow{2}{*}{ 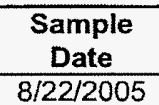 } & \multirow{2}{*}{\multicolumn{3}{|c|}{$\frac{\text { Americium-241 }}{\text { DCi/a }}$}} & \multirow{2}{*}{\multicolumn{3}{|c|}{\begin{tabular}{c}
\multicolumn{2}{c}{ Cesium-137 } \\
pCi/q
\end{tabular}}} & \multirow{2}{*}{\multicolumn{3}{|c|}{\begin{tabular}{|c|c|c|}
\multicolumn{3}{|c|}{ Cobalt-60 } \\
$\mathrm{pCi} / \mathrm{g}$ & $\mathrm{Q}$ & $\mathrm{MDA}$
\end{tabular}}} & \multicolumn{3}{|c|}{ Plutonium-238 } & \multicolumn{3}{|c|}{ Plutonium-239/240 } & \multicolumn{3}{|c|}{ Ruthenium-106 } & \multicolumn{3}{|c|}{ Strontium-90 } \\
\hline & & & $\frac{\mathrm{pC} \text { Cilg }}{1.3 \mathrm{E}-\mathrm{g}}$ & & $\frac{\mathrm{MDA}}{1.3 \mathrm{E}-01}$ & $\frac{\mathrm{pCilg}}{3.5-02}$ & & $\frac{\mathrm{MDA}}{3.5 \mathrm{E}-02}$ & & & & $\frac{p \mathrm{Ci} / \mathrm{g}}{0}$ & $\frac{Q}{U}$ & $\frac{\mathrm{MDA}}{3.7 \mathrm{E}-01}$ & $\frac{p C i / g}{0}$ & $\frac{Q}{U}$ & 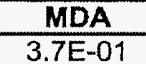 & $\frac{\mathrm{pCilg}}{2.9 \mathrm{E}-01}$ & $\frac{Q}{U}$ & $\frac{\mathrm{MDA}}{2.9 \mathrm{E}-01}$ & $\frac{\mathrm{pCi} / \mathrm{g}}{-3.5 \mathrm{E}-02}$ & $\frac{Q}{U:}$ & $\begin{array}{l}\frac{\mathrm{MDA}}{2.2 \mathrm{E}-01} \\
\end{array}$ \\
\hline Duplicate of & J03WX1 & $8 / 22 / 2005$ & 1.7E-01 & $u$ & 1.7E-01 & $3.3 E-02$ & $u$ & $3.3 \mathrm{E}-02$ & $3.3 \mathrm{E}-02$ & u & 3.3E-02 & 0 & $u$ & $2.8 \mathrm{E}-01$ & $3.7 \mathrm{E}-02$ & $u$ & $2.8 \mathrm{E}-01$ & $2.6 \mathrm{E}-01$ & $u$ & 2.6E-01 & $-3.6 \mathrm{E}-02$ & Iu & $2.4 \mathrm{E}-01$ \\
\hline $\mathrm{A} 2$ & J03WW8 & & $1.4 \mathrm{E}-01$ & $u$ & & $2.5 E$ & $u$ & & & $\bar{U}$ & & & u & & $9.7 \mathrm{E}-02$ & $u$ & & & $\mathrm{U}$ & & & $u$ & $2.8 \mathrm{E}-01$ \\
\hline $\mathrm{A3}$ & Jo3WW9 & $8 / 22 / 2005$ & $2.1 \mathrm{E}-01$ & $U$ & $2.1 \mathrm{E}-01$ & $3.1 \mathrm{E}-02$ & $u$ & $3.1 \mathrm{E}-02$ & $2.6 \mathrm{E}-02$ & $u$ & $2.6 \mathrm{E}-02$ & 0 & $U$ & $2.3 \mathrm{E}-01$ & 0 & $\mathrm{U}$ & $2.3 \mathrm{E}-01$ & $2.4 \mathrm{E}-01$ & $\mathrm{U}$ & $2.4 \mathrm{E}-01$ & $\begin{array}{r}-3.5 \mathrm{E}-02 \\
-4 \mathrm{E}-02 \\
\end{array}$ & $u$ & $\begin{array}{l}2.4 \mathrm{E}-01 \\
.1 \mathrm{E}-01\end{array}$ \\
\hline & & & & & & & & & & & & & & & & & & & & & & & \\
\hline
\end{tabular}

9 Statistical Computation Input Dat

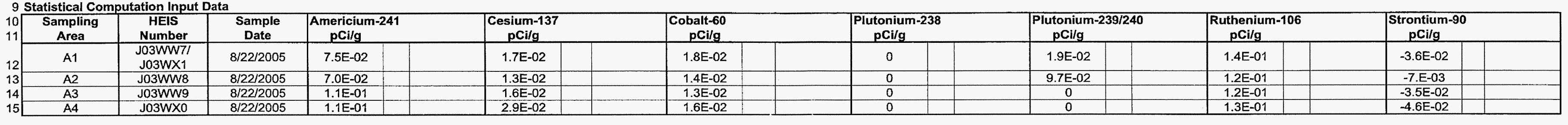

16 Statistical Computations

\begin{tabular}{|c|c|c|c|c|c|c|c|c|c|c|c|c|c|c|c|}
\hline \multirow[b]{3}{*}{$19 \mid$} & & \multicolumn{2}{|c|}{ Americium-241 } & \multicolumn{2}{|l|}{ Cesium-137 } & \multicolumn{2}{|l|}{ Cobalt-60 } & \multicolumn{2}{|c|}{ Plutonium-238 } & \multicolumn{2}{|c|}{ Plutonium-239/240 } & \multicolumn{2}{|c|}{ Ruthenium-106 } & \multicolumn{2}{|c|}{ Strontium-90 } \\
\hline & Statistical value based on & $\begin{array}{r}\text { Radionuclid } \\
\text { nonpara }\end{array}$ & $\begin{array}{l}\text { e data set. Use } \\
\text { metric } z \text {-stat. }\end{array}$ & $\begin{array}{l}\text { Radionuclic } \\
\text { nonpara }\end{array}$ & $\begin{array}{l}\text { data set. Use } \\
\text { netric z-stat. }\end{array}$ & $\begin{array}{l}\text { Radionucli } \\
\text { nonpara }\end{array}$ & $\begin{array}{l}\text { de data set. Use } \\
\text { ametric z-stat. }\end{array}$ & $\begin{array}{r}\text { Radionuc } \\
\text { nonpa }\end{array}$ & $\begin{array}{l}\text { le data set. Use } \\
\text { metric z-stat. }\end{array}$ & $\begin{array}{l}\text { Radionuclide } \\
\text { nonparar }\end{array}$ & $\begin{array}{l}\text { e data set. Use } \\
\text { metric } z \text {-stat. }\end{array}$ & $\begin{array}{l}\text { Radionuclic } \\
\text { nonpara }\end{array}$ & $\begin{array}{l}\text { e data set. Use } \\
\text { metric z-stat. }\end{array}$ & $\begin{array}{r}\text { Radionucli } \\
\text { nonpara }\end{array}$ & $\begin{array}{l}\text { le data set. Use } \\
\text { metric z-stat. }\end{array}$ \\
\hline & & 4 & & 4 & & 4 & & 4 & & 4 & & 4 & & 4 & \\
\hline & $\%<$ Detection limit & $100 \%$ & & $75 \%$ & & $100 \%$ & & $100 \%$ & & $100 \%$ & & $100 \%$ & & $100 \%$ & \\
\hline 21 & mean & $9 . E-02$ & & $1.9 \mathrm{E}-02$ & & $1.5 \mathrm{E}-02$ & & 0 & & $2.9 \mathrm{E}-02$ & & $1.3 \mathrm{E}-01$ & & $-3.1 E-02$ & \\
\hline 22 & st. dev. & $2 . E-02$ & - & 7.E-03 & & 2.E-03 & & 0 & & 4.6E-02 & & $1.0 E-02$ & & 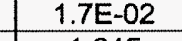 & \\
\hline 23 & Z-statistic & 1.645 & & 1.645 & & 1.645 & & 1.645 & & 1.645 & & $\frac{1.645}{1.2501}$ & & 1.645 & \\
\hline $\begin{array}{l}24 \\
25\end{array}$ & $\begin{array}{r}95 \% \text { UCL on mean } \\
\text { max value }\end{array}$ & $\begin{array}{l}1.1 \mathrm{E}-01 \\
2.2 \mathrm{E}-01\end{array}$ & & $\begin{array}{l}2.4 \mathrm{E}-02 \\
3.5 \mathrm{E}-02\end{array}$ & & $\frac{1.7 E-02}{39 F-02}$ & & $\frac{0}{0}$ & -3 & $\frac{6.7 E-02}{97 F-02}$ & & $\begin{array}{l}\frac{1.3 E-01}{29 E-01} \\
29 E\end{array}$ & & $\begin{array}{l}-1.7 E-02 \\
-7 \mathrm{E}-03\end{array}$ & \\
\hline 26 & Statistical value & $1.1 \mathrm{E}-01$ & 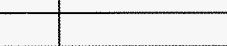 & $2.4 \mathrm{E}-02$ & & $1.7 \mathrm{E}-02$ & & 0 & + & $6.7 \mathrm{E}-02$ & & $1.3 \mathrm{E}-01$ & & $-1.7 \mathrm{E}-02$ & \\
\hline 27 & Background & $\mathrm{NA}$ & & NA & & NA & & NA & & $\mathrm{NA}$ & & NA & & NA & \\
\hline 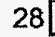 & Statistical value above background & $1.1 \mathrm{E}-01$ & & $2.4 \mathrm{E}-02$ & & $1.7 \mathrm{E}-02$ & & 0 & & 6.7E-02 & & 1.3E-01 & & $-1.7 E-02$ & \\
\hline
\end{tabular}

\section{Split/Duplicate Analysis:}

\begin{tabular}{|c|c|c|c|c|c|c|c|c|c|c|c|c|c|c|c|c|c|c|c|c|c|c|c|c|}
\hline \multirow{2}{*}{$\begin{array}{c}31 \\
32\end{array}$} & \multirow{2}{*}{$\begin{array}{c}\text { Sampling } \\
\text { Area } \\
\end{array}$} & \multirow[b]{2}{*}{\begin{tabular}{|l} 
HEIS Number \\
J03WW7
\end{tabular}} & \multirow[b]{2}{*}{$\frac{\text { Sample Date }}{8 / 222005}$} & \multicolumn{3}{|c|}{ Americium-241 } & \multicolumn{3}{|c|}{ Cesium-137 } & \multicolumn{3}{|c|}{ Cobalt-60 } & \multicolumn{3}{|c|}{ Plutonium-238 } & \multicolumn{3}{|c|}{ Plutonium-239/240 } & \multicolumn{3}{|c|}{ Ruthenium-106 } & \multicolumn{3}{|c|}{ Strontium-90 } \\
\hline & & & & $\frac{\mathrm{pCilg}}{1.3 \mathrm{E}-01}$ & $\frac{a}{u}$ & $\frac{\mathrm{MDA}}{1.3 \mathrm{E}-01}$ & $\frac{\mathrm{pCilg}}{3.5 \mathrm{E}-02}$ & $\frac{Q}{U}$ & $\frac{\text { MDA }}{3.5 \mathrm{E}-02}$ & $\frac{\mathrm{pCi} / \mathrm{g}}{3.9 \mathrm{E}-02}$ & $\frac{Q}{U}$ & $\frac{\text { MDA }}{3.9 E-02}$ & $\frac{\mathrm{pCilg}}{0}$ & $\frac{a}{u}$ & $\begin{array}{l}\text { MDA } \\
3.7 E-01\end{array}$ & $\frac{\mathrm{pcilg}}{0}$ & $\frac{Q}{U}$ & $\begin{array}{l}\text { MDA } \\
3.7 \mathrm{E}-01\end{array}$ & $\begin{array}{c}\frac{\mathrm{pCi} / \mathrm{g}}{2.91} \\
2 . \mathrm{E}-01\end{array}$ & $\frac{Q}{U}$ & $\begin{array}{c}\frac{\mathrm{MDA}}{2.9 \mathrm{E}-01} \\
\end{array}$ & $\begin{array}{c}\text { pCilg } \\
-3.5-02\end{array}$ & $\frac{a}{u}$ & $\frac{\mathrm{MDA}}{2.2 \mathrm{E}-01}$ \\
\hline & Duplicate of & Jo3WX1 & $8 / 22 / 2005$ & $1.7 \mathrm{E}-01$ & $u$ & 1.7E- 01 & $3.3 \mathrm{E}-02$ & $u$ & $3.3 \mathrm{E}-02$ & 3.3E-02 & $u$ & $3.3 E-02$ & 0 & $u$ & $2.8 \mathrm{E}-01$ & $3.7 E-02$ & $u$ & $2.8 \mathrm{E}-01$ & $2.6 \mathrm{E}-01$ & $u$ & $2.6 E-01$ & $-3.6 \mathrm{E}-02$ & $u$ & $2.4 E-01$ \\
\hline & $\begin{array}{l}\text { Split of } \\
\end{array}$ & $\mathrm{J} 03 \mathrm{~W} \times 2$ & $8 / 22 / 2005$ & $7.65 \mathrm{E}-02$ & U & 3.56E-01 & $5.01 \mathrm{E}-03$ & $u$ & $1.48 \mathrm{E}-02$ & $-4.26 \mathrm{E}-03$ & u & 1.53E-02 & $0.00 E+00$ & U & $6.50 \mathrm{E}-02$ & $0.00 E+00$ & $u$ & $6.50 \mathrm{E}-02$ & $5.01 \mathrm{E}-02$ & U & 1.21E-01 & $5.01 \mathrm{E}-02$ & $u$ & $1.21 \mathrm{E}-01$ \\
\hline \multirow{3}{*}{38} & & \multirow{2}{*}{\multicolumn{2}{|c|}{ TDL }} & \multirow{3}{*}{\multicolumn{3}{|c|}{$\frac{1}{\text { No-Stop (acceptable) }}$}} & \multirow{3}{*}{\multicolumn{3}{|c|}{$\begin{array}{c}0.1 \\
\text { No-Stop (acceptable) }\end{array}$}} & \multirow{3}{*}{\multicolumn{3}{|c|}{ No-Stop (acceptable) }} & \multirow{3}{*}{\multicolumn{3}{|c|}{ No-Stop (acceptable) }} & & & & & $\mathrm{NA}$ & & & 1 & \\
\hline & \multirow{2}{*}{$\begin{array}{l}\text { Duplicate } \\
\text { Analysis }\end{array}$} & & & & & & & & & & & & & & & \multirow{2}{*}{\multicolumn{3}{|c|}{ No-Stop (acceptable) }} & \multirow{2}{*}{\multicolumn{3}{|c|}{ No-Stop (acceptable) }} & \multirow{2}{*}{\multicolumn{3}{|c|}{ No-Stop (acceptable) }} \\
\hline & & \multirow{2}{*}{\multicolumn{2}{|c|}{$\begin{array}{c}\text { Both > 5xTD } \\
\text { RPD }\end{array}$}} & & & & & & & & & & & & & & & & & & & & & \\
\hline & \multirow{2}{*}{ Split Analysis } & & & \multicolumn{3}{|c|}{ No-Stop (acceptable) } & \multirow{2}{*}{\multicolumn{3}{|c|}{ No-Stop (acceptable) }} & \multirow{2}{*}{\multicolumn{3}{|c|}{ No-Stop (acceptabie) }} & \multirow{2}{*}{\multicolumn{3}{|c|}{ No-Stop (acceptable) }} & \multirow{2}{*}{\multicolumn{3}{|c|}{ No-Stop (acceptable) }} & \multirow{2}{*}{\multicolumn{3}{|c|}{ No-Stop (acceptable) }} & \multirow{2}{*}{\multicolumn{3}{|c|}{ No-Stop (acceptable) }} \\
\hline & & \multicolumn{2}{|c|}{$\begin{array}{c}\text { Both }>5 \times \text { TDL? } \\
\text { RPD }\end{array}$} & & & & & & & & & & & & & & & & & & & & & \\
\hline
\end{tabular}

43 HEIS = Hanford Environmental Information System

$44 \mathrm{MDA}=$ minimum
$45 \mathrm{NA}=$ not applicable

$46 \mathrm{Q}=$ qualifier

$47 \mathrm{TDL}=$ target detection limit
$48 \mathrm{U}=$ =ndetected 


\section{DISTRIBUTION}

U.S. Department of Energy

Richland Operations Office

D. C. Smith (5)

A3-04

DOE-RL Public Reading Room

$\mathrm{H} 2-53$

Fluor Hanford, Inc.

J. P. Shearer (WIDS)

A0-21

Washington Closure Hanford

K. A. Anselm

$\mathrm{H} 9-02$

R. A. Carlson

$\mathrm{X} 0-17$

S. W. Clark

$\mathrm{H} 9-01$

F. M. Corpuz

L6-06

J. W. Darby

L6-06

L. A. Dietz

$\mathrm{HO}-23$

L. M. Dittmer

$\mathrm{H} 9-02$

R. B. Kerkow

L6-06

J. A. Lerch

$\mathrm{H} 0-23$

T. H. Mitchell

$\mathrm{H} 9-01$

J. E. Thomson

$\mathrm{HO}-23$

Records and Document Control

$\mathrm{HO}-30$

Hanford Technical Library

P8-55 
CVP-2005-00009

Rev. 0

Distr-2 